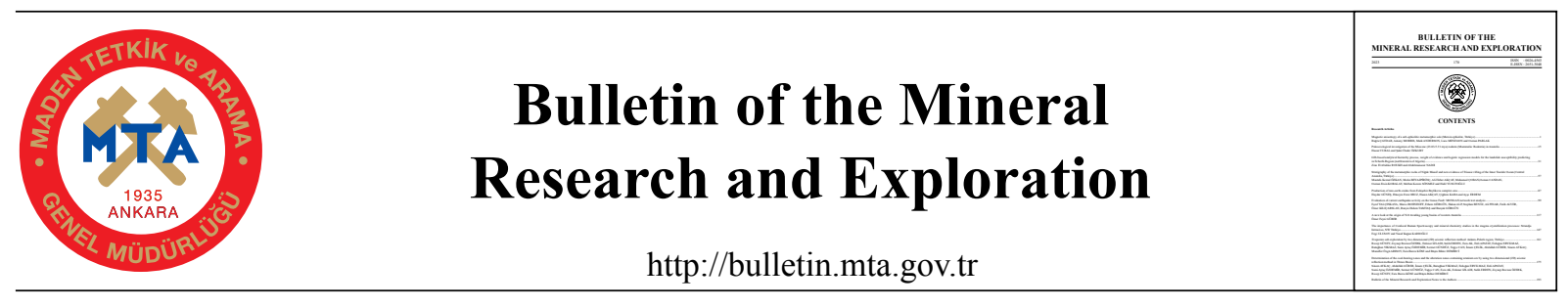

\title{
A new look at the origin of N-S trending young basins of western Anatolia
}

\author{
Ömer Feyzi GÜRER ${ }^{a^{*}}$ \\ ${ }^{\mathrm{a}}$ Kocaeli University, Engineering Faculty, Department of Geological Engineering, Kocaeli, Türkiye
}

Research Article

Keywords:

Western Anatolia, Late Cenozoic, Contractional Tectonic, N-S Basins, Neotectonic.
Received Date: 10.11.2021 Accepted Date: 31.01 .2022

\begin{abstract}
In the western Anatolia, the tectonic regime transitioned from crustal shortening to extension during Late Cenozoic time and evidence of this event was imprinted on basement lithologies and N-S and E-W oriented two distinct basin sub-types. Here, we examined the exhumation mechanismof the Menderes massif that forms the basement of these basins from a different perspective. The N-S oriented basins overlying different basement rock types were re-evaluated based on new evidence that has potential to put new constrains for interpreting the tectonic evolution of the area. Unroofing of the Menderes Massif must have developed due to compressional core complex. Per the model generated from our observations, we propose that the western Anatolia underwent a N-S contraction during the Early-Middle Miocene time. In this period from Marmara Sea at north to Mediterranean Sea at south, numerous basins, as in Gördes and Demirci, were bound by N-S oriented oblique faults. Evidence of contraction in the region during Early Middle Miocene time is understood by N-S oriented obique, strike-slip faults, folds, and reverse faults. Starting from the Plio-Quaternary time, the contractional regime was shifted to extension and ensuing E-W oriented grabens were formed in Gediz, Büyük Menderes, and Gökova. The structural deformation associated with these E-W oriented grabens are normal faults and related open folds. Geological evidence of multigeneration extension is recognized in the basins and basin-filling deposits throughout the Neogene to Quaternary time.
\end{abstract}

\section{Introduction}

Western Anatolia was exposed to the mutual interaction of contraction and extension systems during the Late Cenozoic. According to their position, two groups of basins are mainly present in the region as E-W and N-S trending, and there are several discussions on them. The most important of the major issues is to reveal the main data of the compressional and extensional tectonics and their relations and, accordingly, dating the initial ages of compressional and extensional tectonics. There is no consensus has yet been reached on these issues (Şengör, 1979; Seyitoğlu and Scott, 1991; Y1lmaz et
The 11th Development Plan, set Türkiye's development 2014; Sözbilir et al., 2011; Özburan and Gürer, 2012; Gürbüz et al., 2012; Sangu et al., 2020). Three main problems have not been fully reconciled regarding the Neogene-Quaternary geology and structural elements of the region. These are;

1) What is the origin of extension?

Six different models have been proposed to answer this question: a) the southward rollback of the African plate or the back-arc spreading model (McKenzie 1978; Jackson and McKenzie 1988), b) orogenic collapse model (Dewey 1988; Seyitoğlu

Citation Info: Gürer, F. Ö. 2023. A new look at the origin of N-S trending young basins of western Anatolia. Bulletin of the Mineral Research and Exploration 170, 117-146. https://doi.org/10.19111/bulletinofmre.1066949

*Corresponding author: Ömer Feyzi GÜRER, ofgurer@kocaeli.edu.tr 
and Scott 1991; McClusky et al., 2000), c) tectonic escape model (Dewey and Şengör 1979; Şengör 1987), southward retreat of the northward subducting African slab due to post-orogenic collapse (Gautier et al., 1999; Jolivet, 2001), e) two-phased extension model (orogenic collapse/rollback of the subducting slab and tectonic escape) (Koçyiğit et al., 1999; Y1lmaz et al., 2000; Bozkurt 2000, 2001b, 2003, 2004; Purvis and Robertson 2004; Bozkurt and Rojay 2005), f) extension in the Aegean Region due to different convergence rates towards the northeast between African slab and the Eurasian lithosphere. The faster southwestward motion of Greece than that in Cyprus and Anatolia resulted in the Aegean-West Anatolian Rift (Doglioni et al., 2002).

\section{2) What is the origin of the N-S basins?}

For the origin of N-S trending basins, one of the following six models has been suggested: a) the basins developed as paleotectonic Tibetan type crossgrabens under N-S compression, then changed into neotectonic Aegean type cross-grabens under N-S extensional regime (Şengör et al., 1985; Şengör, 1987; Görür et al., 1995). b) the basins developed as Aegeantype cross-grabens, similar to the strike-slip basins associated with syn-sedimentary volcanism (Bozkurt, 2003). c) the third model suggests that the N-S basins are related to the strike-slip faults developed under N-S compression and E-W extension (Yilmaz et al., 2000; Gürer et al., 2009, 2013; Özburan and Gürer, 2012). d) The basins in N-S and E-W directions developed simultaneously during the N-S extensional regime since the late Oligocene-Early Miocene. The extension was attributed to late orogenic collapse, which occurred just after the Paleogene compression had been ended (Seyitoğlu and Scott, 1991, 1994). e) N-S trending basins are not extension-related, they are intermountain basins (İnci, 1998, 2002). f) the basins are either supradetachment basins or depositions occurred in transtensional basins (Purvis and Roberston, 2004; Seyitoğlu et al., 2004; Ersoy et al., 2011; Sözbilir et al., 2011; Sümer et al., 2020).

3) Is the extension in the region continuous or discontinuous?

a) According to some researchers, the extensional system was continuously active from the Late Oligocene to the Quaternary (Seyitoğlu and Scott,
1991; Işık et al., 2003). Seyitoğlu and Işık (2015) claimed that there was no compressional regime in the region that continued until the Late Pliocene or between Miocene-Pliocene, even for a short period. b) Some other authors have proposed a multistage extensional history with two different suggestions. The first group suggested that the Late OligoceneEarly Miocene stretching could not be responsible for all extensional tectonic history and that continental extension in the region was not a continuous event (Purvis and Robertson, 2004; Bozkurt and Sözbilir, 2004; Bozkurt and Rojay, 2005). According to this model, the stretching direction in Western Anatolia has always been N-S. The second group suggested multiple stretching phases in different directions (Koçyiğit et al., 1999; Yılmaz et al., 2000; Genç et al., 2001; Gürer and Y1lmaz 2002; Ring et al., 2003; Gürer et al., 2001, 2003, 2006, 2009, 2021; Koçyiğit, 2005; Kaymakçı, 2006; Çemen et al., 2006; Koçyiğit and Deveci, 2007; Alçiçek and Ten Veen, 2008; Gürbüz et al., 2012; Özburan and Gürer, 2012; Gürboğa et al., 2013).

The largest E-W trending grabens are Bakırçay, Kütahya, Simav, Gediz, Küçük Menderes, Büyük Menderes and Gökova grabens. These grabens and the normal faults restricting them are the most seismically active structures of western Anatolia. There is no consensus on the onset of the formation of E-W trending grabens. However, some researchers, based on paleontological and geochronological data, suggested that grabens began to develop in the Early Miocene (Seyitoğlu and Scott, 1991, 1996), in the Late Miocene (Şengör and Y1lmaz, 1981; Şengör et al., 1985; Şengör 1987; Kaymakçı, 2006), or in the Plio-Quaternary (Dewey, 1988; Yilmaz et al., 2000; Sarıca, 2000; Bozkurt, 2000, 2001b; Gürer et al., 2009; 2013; Özburan and Gürer, 2012; Yılmaz, 2017a, b). Other structural elements of Western Anatolia are the $\mathrm{N}-\mathrm{S}$ trending basins and uplifts. These basins, mainly Urla, Çubukludağ, Seyitömer, Sabuncupınar, Gördes, Demirci, Selendi-Uşak, Ören, Eskihisar and Tınaz, join-up with the E-W grabens at high angles.

This article aims to give brief information about the basins in Western Anatolia and reevaluate the debates, particularly on the formation of N-S trending basins. These evaluations will be discussed within the scope of the author's studies in the region and other 
publications from the literature. Although the origin of the crustal extension is controversial, it is possible to examine the hypotheses about the continuity of the extension with detailed geological studies, especially in the basins.

\section{Regional Geological Setting}

There are two main types of rock groups in Western Anatolia as the pre-Neogene basement and the Neogene-Quaternary sequences (Figure 1). From north to south, the main tectonic units are a) Sakarya Continent, b) İzmir-Ankara Suture Zone, c) Menderes Massif, d) Lycian Nappes, and e) Taurides. These tectonic units were amalgamated by the closure of the northern branch of Neo Tethys (Vardar-İzmir-Ankara) in the Late Cretaceous-Eocene interval.

\subsection{Pre-Neogene Basement Units}

In Western Anatolia, pre-Neogene structural units with different geological features such as Sakarya

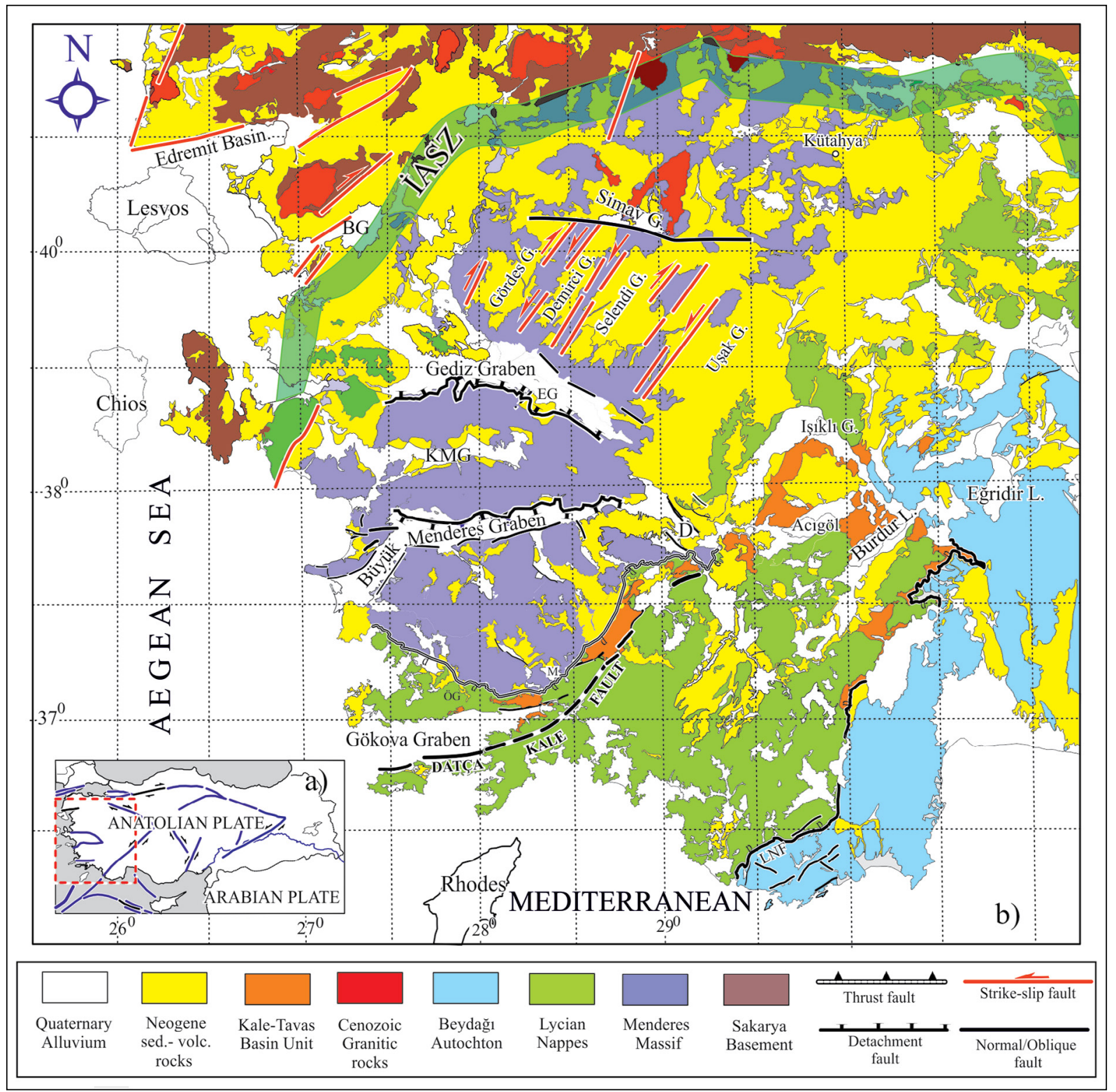

Figure 1- a) Outline map of Türkiye and b) Simplified geological map of Western Anatolia (simplified from Konak, 2002, Konak and Şenel, 2002). D: Denizli, M: Muğla, AH: Alaşehir Basin, KSH: Kuşadası-Söke Basin, ÖG: Ören Basin, BH: Bakırçay Basin, KMG: Küçük Menderes Graben, İAKZ: İzmir-Ankara Suture Zone. 
Continent, İzmir-Ankara Suture Zone, Menderes Massif, Lycian Nappes, and Taurides are present. These structural units will be briefly introduced below, from north to south.

\subsubsection{Sakarya Continent}

Sakarya Continent is characterized by a strongly deformed Triassic basement with various metamorphics, namely the Karakaya Complex, which is covered by an extensive unconformity by Liassic conglomerate and sandstones, which pass to middle Jurassic-Lower Cretaceous carbonates and to Upper Cretaceous flysch (Bingöl et al. 1975; Okay, 1989; Genç and Yılmaz, 1995). Sakarya Continent is a unit bounded by the İzmir-Ankara Suture to the south and the Intra-Pontide Suture to the north. Based on consisting of several pre-Alpine sequences as tectonic assemblages presenting completely different geological ages in the basement, the unit is assumed as a composite terrane (Göncüoğlu et al., 1997).

\subsubsection{Izmir-Ankara Suture Zone}

İzmir-Ankara Suture Zone represents the northern branch of Neo-Tethys. This suture, which separates the Sakarya Zone from the Anatolide-Taurides, is generally accepted as the major Tethys suture in Türkiye (Y1lmaz, 1981). The northern branch of Neo-Tethys was consumed beneath the Sakarya Continent by northward subduction during the Cretaceous-Eocene. This suture zone contains intense HP/LT blueschist facies metamorphism in some parts (Sherlock et al., 1999; Okay, 2002; Çelik et al., 2011). It also contains a number of fragmented ophiolite slices, which are interpreted to represent remnants of the Tethys oceanic lithosphere (Göncüoğlu et al., 2000). These oceanic lithosphere fragments were thrusted over the passive margin of Anatolide-Tauride platform (Şengör and Yılmaz, 1981; Gürer and Aldanmaz, 2002; Çelik et al., 2011).

\subsubsection{Menderes Massif}

The Menderes Massif is accepted as one of the metamorphic core complexes in which lowermiddle crustal rocks outcrop (Bozkurt et al., 1993; Bozkurt and Park, 1994; Hetzel et al., 1995; Emre and Sözbilir, 1997; Gessner et al., 2001a, b; Ring et al., 2003; Seyitoğlu et al., 2004). This crystalline complex is tectonically overlain by different tectonic units or zones such as the Lycian nappes in the south, and in the north and northwest by the Tavşanlı zone, Selçuk mélange, the Dilek Nappe, the Afyon zone, Ören Unit with high pressure metamorphism (Okay, 1981; Sherlock et al., 1999; Candan et al., 2001, 2005; Önen and Hal, 2000; Güngör and Erdoğan, 2001; Pourteau et al., 2010; Y1lmaz, 2017a). In the west, the metamorphic rocks extending along the Dilek Peninsula are accepted as the eastern continuation of the Central Aegean Region Cycladic Massif, based on their geological and metamorphic characteristics (Candan et al., 2005; Rimmele et al., 2003, 2005; Gessner et al., 2001a, $b$; Van Hinsbergen and Schmid, 2012; Y1lmaz, 2017a). The massif is covered by Neogene-Quaternary sedimentary/volcanic units in many areas.

The tectonic position and evolution of the Menderes massif is controversial. The ongoing debates about the massif concerns the type and timing of metamorphism, magmatism, and deformation (Y1lmaz, 2017a), the overall structure of the massif, how and when the massif's lower-middle crustal rocks were exhumed, and the relationship of the massif to the other surrounding massifs (Whitney and Bozkurt, 2002). The debates are especially related to the structural position of the southern part of the Menderes Massif. Suggested models are mainly as follows: a series of north-vergent thrusts within the massif (Bozkurt and Park, 1994) (Figure 2a), southern Menderes submassif as a large north-vergent recumbent fold (Okay, 2001) (Figure 2b), a series of nappes stacked during south-directed thrusting (Ring et al., 1999; Gessner et al., 2001b). It has been suggested that the Menderes Massif, which was thought to have a simple structure in previous studies, presents a complex internal structure defined by the Late Alpine compressional tectonic product thrust faults (Partzsch et al, 1998; Candan and Dora, 1998; Gessner et al., 1998; Ring et al., 1999, 2003; Dora et al., 2001; Regnier et al., 2003; Ring and Collins, 2005; Bozkurt, 2007). The metamorphic rocks of the Central Menderes Massif consist of four nappes stacked during plate convergence from Late Cretaceous to Eocene along the İzmir-Ankara Suture Zone (Ring et al., 1999; Van Hinsbergen, 2010; Gessner et al., 2013). From the bottom to the top, these nappes include the Bayındır, Bozdağ, Çine and Selimiye nappes that are structurally overlain 


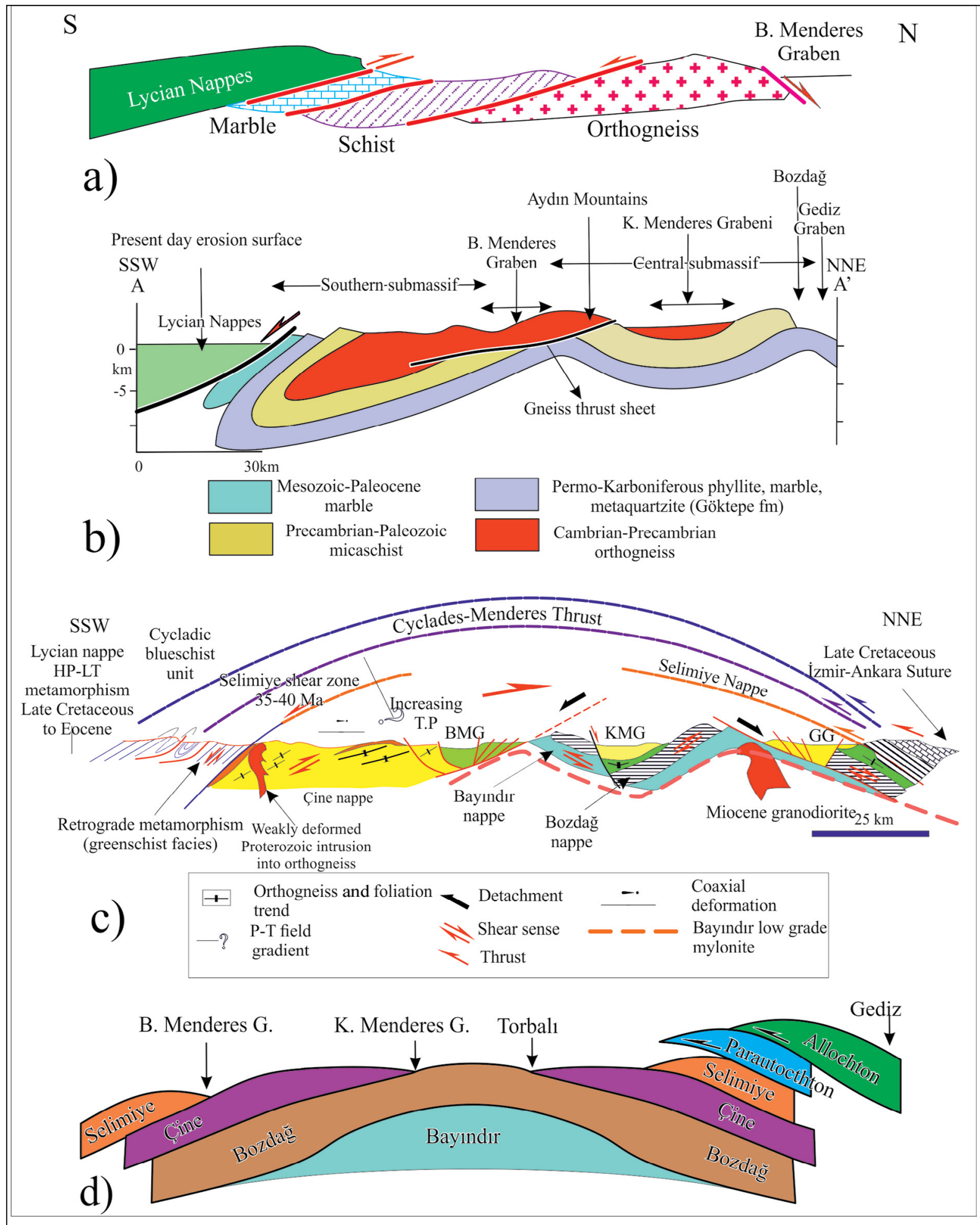

Figure 2- a) the north-vergent thrust model in the Menderes Massif (Bozkurt and Park, 1999), b) a schematic cross-section illustrating the recumbent fold in the Menderes Massif (Okay, 2001), c) the interpreted cross-section of the Menderes Massif by Gessner et al. (2001c), Lips et al. (2001), Regnier et al. (2007). ${ }^{40} \mathrm{Ar} /{ }^{39} \mathrm{Ar}$ white mica ages for the Selimiye shear zone were taken from Hetzel and Reischmann (1996). The Bayındır low-grade mylonite zone is shown with a thick dashed line. BMG: Büyük Menderes Graben, GG: Gediz Graben, KMG: Küçük Menderes Graben (Regnier et al., 2007) and d) an interpreted cross-section showing the positions of different thrust slices along the Menderes Massif (Y1lmaz, 2017a). 
by the Cycladic blueschist unit in the west (Ring et al., 1999; Gessner et al., 2013; Heineke et al., 2019). Regnier et al. (2007) demonstrated the napped internal structure of the massif by conducting a study focusing on metamorphic conditions along the contact of orthogneiss and surrounding metasedimentary rocks in the southern Menderes Massif (Figure 2c). According to Yilmaz (2017a), the Menderes Massif has been subjected to semi-brittle to brittle, N-S compressional deformation, which causes the shortening, thickening and imbrication in the entire region. Thick-skinned deformation has occurred in the Menderes Massif and its tectonic components have been structurally rearranged. Deep-seated metamorphic rocks (core rocks) were thrusted over the cover rocks (Figure 2d, Yilmaz, 2017a).

A large number of studies have been conducted on the metamorphisms and deformations of the Menderes Massif and its surrounding massifs (Table 1). In these studies, different opinions have been put forward about the deformation times of the massif. Ages varying from Eocene to Miocene for compression, while from Miocene to Pliocene for N-S trending extension in the massif have been suggested.

\subsubsection{Lycian Nappes}

The Lycian nappes form a nappe stack consisting of fragmented ophiolites forming the uppermost nappe, together with the slices of the Western Tauride metamorphic basement and the overlying Mesozoic platform carbonates. Lycian nappes are widespread in the south of the Menderes Massif (Figure 3). Lycian nappes as in tectonic slices tectonically overlie the Beydağ1 parautochthon of the Western Taurides at the south (Poisson, 1977, Gutnic et al., 1979; Ricou et al., 1979; Collins and Robertson, 1998; Ersoy, 1990). It has been accepted that the Lycian nappes were transported from the Neo-Tethys Ocean at the north of the Menderes Massif in the Late CretaceousLate Miocene interval as tectonic slices, over the massif from north to south and emplaced in the region (Şengör and Yılmaz, 1981; Şengör et al., 1985; Okay, 1989; Collins and Robertson, 1998).

\subsubsection{Taurides}

In the west of the Taurides, located in the south of Türkiye, rock units, which are mostly allochthonous, developed in the Precambrian-Quaternary interval crop out. Beydağları autochthon is a carbonate platform during the Mesozoic and witnessed the emplacement of Antalya and Alanya nappes at the end of the Mesozoic and/or in Paleocene, and the Lycian nappes at the end of the Early Miocene and the beginning of the Middle Miocene (early Langhian). The first two of these nappes are south-originated, while the Lycian nappes of north-origin (Konak, 2007). The northern branch of the Neo-Tethys Ocean was closed in the Eocene as a result of the collision of the Sakarya zone in the north and the Tauride-Anatolide Platform in the south (Şengör and Yılmaz, 1981). The first thrusting of ophiolitic nappes and platform successions from north to south over the Tauride platform initiated in the Early Eocene, and its final emplacement lasted until the Middle Pliocene (Poisson, 1977; Y1lmaz et al., 2000).

\subsection{Neogene-Quaternary Basins}

Neogene-Quaternary sequences are mainly found in basins in two different directions. The N-S trending basins are rhomboidal- or trough-shaped, with an average length of $20-25 \mathrm{~km}$ and a width of $5-10 \mathrm{~km}$ (Figure 1). The faults controlling the opening of the basins are generally oblique faults with a dominant strike-slip component (Yilmaz et al., 2000; Bozkurt 2003; Gürbüz et al., 2012; Gürer et al., 2001, 2009, 2013; Ersoy et al., 2011, 2014; Y1lmaz 2017a, b). The basins, generally have similar stratigraphy, and are filled with terrestrial sediments and volcanics, presenting lateral and vertical changes within the facies and lithologies. The sediments were mainly deposited in alluvial fan, fluvial and lacustrine environments. The succession, which starts with blocky conglomerate and conglomerate at the basin margins, then passes into alternations of sandstone and mudstone, and into marl and limestones in the basin interior. In addition to the sediments, volcanics in andesite, latite and dacite composition and volcanoclastic rocks are commonly found in the northern basins (Y1lmaz, 1989; Y1lmaz et al., 2000). Basin fills can reach a thickness of $1500 \mathrm{~m}$.

The N-S oriented basin sequences were influenced by syn- and post-depositional open-closed folds and reverse faults at different scales and were deformed. Miocene deposits of the basins located in the north of the Gediz Graben were deformed by wide folds with parallel axes to the basin margins (Y1lmaz et al., 
Table 1- Views on the metamorphism and deformation of the Menderes Massif and its surrounding massifs.

\begin{tabular}{|c|c|c|c|}
\hline Reference & Deformation Components & Metamorphism Conditions & Time of Deformation \\
\hline \multirow{4}{*}{$\begin{array}{l}\text { Ring et al., } 1999 \\
\quad \text { Samos }\end{array}$} & $\begin{array}{l}\text { D1-D2, WNW-ESE oriented nappe } \\
\text { emplacement }\end{array}$ & $\begin{array}{l}\text { Blueschist and blueschist-greenschist } \\
\text { transitional metamorphism (M1) D2, } \\
\text { Blueschist metamorphism in Kerketas } \\
\text { nappe (M2) }\end{array}$ & Eocene-Early Oligocene \\
\hline & $\begin{array}{l}\text { D3, Oligocene-Miocene horizontal } \\
\text { stretching, }\end{array}$ & $\begin{array}{l}\text { Crustal horizontal stretching, then } \\
\text { greenschist metamorphism (M3) }\end{array}$ & Early Oligocene \\
\hline & $\begin{array}{l}\mathrm{D} 4,<8.6 \text { and } 9 \mathrm{My}, \mathrm{E}-\mathrm{W} \text { short-term } \\
\text { compression }\end{array}$ & The cause of this event is unknown. & Miocene \\
\hline & $\begin{array}{l}\text { D5, }<8.6 \text {-Recent N-S oriented normal } \\
\text { faulting phase }\end{array}$ & & Late Tortonian- Recent \\
\hline \multirow{2}{*}{$\begin{array}{l}\text { Bozkurt and Park, } \\
1999 \text { Southern } \\
\text { Menderes Massif }\end{array}$} & D1 related deformation; $\mathrm{N}-\mathrm{S}$ & $\begin{array}{l}\text { M1 Barrovian type regional } \\
\text { metamorphism }\end{array}$ & $\begin{array}{l}\text { Early Eocene-Early } \\
\text { Oligocene }\end{array}$ \\
\hline & D2, WNW-ESE trending & ? & $\begin{array}{l}\text { Late Oligocene-Early } \\
\text { Miocene }\end{array}$ \\
\hline \multirow{2}{*}{$\begin{array}{c}\text { Gessner et al., } 2001 b \\
\text { Menderes Nappes }\end{array}$} & $\begin{array}{l}\mathrm{D}_{\mathrm{PA}}, \text { compression, top to the NE sense of } \\
\text { shear }\end{array}$ & Amphibolite facies metamorphism & Pre-Alpine (Proterozoic) \\
\hline & $\mathrm{D}_{\mathrm{A} 3+\mathrm{D} 4}$, compression, top to the $\mathrm{S}$ & Greenschist facies & Late Oligocene \\
\hline \multirow{2}{*}{$\begin{array}{c}\text { Gessner et al., 2001a } \\
\text { Menderes Massif }\end{array}$} & First cooling phase & Temperature over $110^{\circ} \mathrm{C}$ & $\begin{array}{l}\text { Late Oligocene-Middle } \\
\text { Miocene }\end{array}$ \\
\hline & Second cooling phase & Temperature below $60^{\circ} \mathrm{C}$ & Pliocene-Pleistocene \\
\hline \multirow{3}{*}{$\begin{array}{c}\text { Rimmele et al., } \\
2003 \\
\text { South of Menderes } \\
\text { Massif }\end{array}$} & $\begin{array}{l}1^{\text {st }} \text { phase, top to the } \mathrm{N} \text { sense of shear, } \\
\text { compression }\end{array}$ & $\begin{array}{l}\text { HP association magnesiocarpholite- } \\
\text { kyanite }\end{array}$ & Late Cretaceous-Eocene \\
\hline & $2^{\text {nd }}$ phase, top to the $\mathrm{N}$ sense of shear & $\begin{array}{l}\text { AMM peak, gradual cooling (Late } \\
\text { Eocene) } \\
\text { HP metamorphism in the cover } \\
\text { metaconglomerate. } \\
\text { Northward thrust of the Lycian } \\
\text { Nappes over the Menderes Massif, } \\
\text { Reactivation of the Menderes-Lycian } \\
\text { contact as a NE shear zone in the upper } \\
\text { plate leading to the exposure of the } \\
\text { Lycian HP rocks. } \\
\end{array}$ & Paleocene-Eocene \\
\hline & $3^{\text {rd }}$ phase & $\begin{array}{l}\text { N-S bi-directional extension, Top to } \\
\text { the SW shear sense in the chloritic } \\
\text { shear bands in the late exhumation } \\
\text { phase. }\end{array}$ & Oligo-Miocene \\
\hline \multirow{2}{*}{$\begin{array}{c}\text { Rimmele et al., } 2003 \\
\text { South of Menderes } \\
\text { Massif }\end{array}$} & $\begin{array}{l}\text { Top to the NE shearing concurrent with the } \\
\text { syn-orogenic extension and exhumation of } \\
\text { the Cyclades }\end{array}$ & HP-LT & Eocene \\
\hline & $\begin{array}{l}\text { Extension, NE trending shear in the } \\
\text { regional upper plate }\end{array}$ & & Miocene \\
\hline \multirow{3}{*}{$\begin{array}{l}\text { Ring et al., } 2003 \\
\text { Gördes-Çine }\end{array}$} & Napping & & Late Cretaceous-Tertiary \\
\hline & $\begin{array}{l}\text { Extension, Rapid Cooling, southward } \\
\text { movement of the upper plate }\end{array}$ & & $\begin{array}{l}\text { Late Oligocene (25My) - } \\
\text { Miocene }\end{array}$ \\
\hline & Extension, Cooling & & Pliocene \\
\hline
\end{tabular}


Table 1- Continued.

\begin{tabular}{|c|c|c|c|}
\hline \multirow{3}{*}{$\begin{array}{c}\text { Regnier et al., } \\
2003 \\
\text { South of Menderes } \\
\text { Massif }\end{array}$} & $\begin{array}{l}\text { Selimiye shear zone, MM burial, top to the } \\
\text { S shear sense }\end{array}$ & $\begin{array}{l}\text { Greenschist and amphibolite facies, } \\
\text { degree of metamorphism decreases } \\
\text { from bottom to top in the Selimiye } \\
\text { Nappe. }\end{array}$ & Eocene \\
\hline & Çine Nappe & $\begin{array}{l}\text { Max. P-T conditions, } 8-11 \text { kbar and } \\
600-650^{\circ} \mathrm{C}\end{array}$ & $\begin{array}{l}\text { ca. } 550 \text { My was stated } \\
\text { for the amphibolite facies } \\
\text { metamorphism }\end{array}$ \\
\hline & $\begin{array}{l}\text { No evidence for the northward thrust of } \\
\text { the upper plate for being an early Alpine } \\
\text { phase. }\end{array}$ & & \\
\hline \multirow{4}{*}{$\begin{array}{l}\text { Ring et al., } 2007 \\
\text { Samos, Menderes } \\
\text { Massif }\end{array}$} & $\begin{array}{l}\text { Ampelos/Dilek nappe was thrusted } \\
\text { southward over the MM with greenschist } \\
\text { facies, Cyclades-Menderes thrust, cutting a } \\
30 \text { to } 40 \mathrm{~km} \text { thick crust. }\end{array}$ & & \multirow{4}{*}{$\begin{array}{l}\text { Detailed } \mathrm{Rb}-\mathrm{Sr} \text { and }{ }^{40} \mathrm{Ar}{ }^{39} \mathrm{Ar} \\
\text { dating of mylonites indicate } \\
\text { that both shear zones operated } \\
\text { between } 42-32 \mathrm{My} \text {. }\end{array}$} \\
\hline & $\begin{array}{l}\text { The upper contact of the Ampelos/Dilek } \\
\text { wedge is the top to the NE Selçuk normal } \\
\text { shear zone where the Ampelos/Dilek nappe } \\
\text { exhumes about } 30-40 \mathrm{~km} \text {. }\end{array}$ & & \\
\hline & $\begin{array}{l}\text { No evidence for a duration of } 10 \mathrm{Myr} \\
\text { episodic motion of shear zones, implying } \\
\text { both shear zones worked steady, non- } \\
\text { episodic manner (42-32 My). }\end{array}$ & & \\
\hline & $\begin{array}{l}\text { Our data provide supporting evidence for } \\
\text { that simultaneous thrusting and normal } \\
\text { shear can result in early exposure of deep- } \\
\text { seated rocks. }\end{array}$ & & \\
\hline \multirow{3}{*}{$\begin{array}{c}\text { Ten Veen et al., } 2009 \\
\text { Menderes Massif }\end{array}$} & $\begin{array}{l}1^{\text {st }} \text { phase, detachment faulting in which } \\
\text { the upper plate moves to the north in the } \\
\text { uplift of Menderes Massif and accordingly } \\
\text { the southeastward sliding of the Lycian } \\
\text { Nappes. These faults reactivated in } \\
\text { younger deformation stages. }\end{array}$ & & Early-Middle Miocene \\
\hline & $\begin{array}{l}2^{\text {nd }} \text { phase, NNE-SSE and ENE-WSW } \\
\text { oriented extension, E-W trending main } \\
\text { grabens }\end{array}$ & & Late Miocene-Late Pliocene \\
\hline & $\begin{array}{l}3^{\text {rd }} \text { phase, Stage } 2 \text { type of extensions are } \\
\text { dominant in W Anatolian Graben Region } \\
\text { and Lycian Taurids. }\end{array}$ & & Post-Pliocene \\
\hline $\begin{array}{l}\text { Van Hinsbergen, } \\
2010 \\
\text { Menderes Massif }\end{array}$ & $\begin{array}{l}\text { MM formed a rectangular, NE-SW } \\
\text { oriented, } 150 \times 100 \mathrm{~km} \text { size tectonic } \\
\text { window. }\end{array}$ & & Early Miocene \\
\hline \multirow{2}{*}{$\begin{array}{l}\text { Van Hinsbergen and } \\
\text { Schmid } 2012 \\
\text { Aegean Region } \\
\end{array}$} & $1^{\text {st }}$ phase, $110 \mathrm{~km}$ extension & & Between 25-15 My \\
\hline & Most of the $2^{\text {nd }}$ extension occurred & & After 15 My (max. $290 \mathrm{~km})$ \\
\hline \multirow{2}{*}{$\begin{array}{l}\text { Cenki-Tok et al., } \\
2016 \\
\text { North of Menderes } \\
\text { Massif }\end{array}$} & Compression & $\begin{array}{l}\text { Extensive amphibolite facies } \\
\text { metamorphism reaching the peak. } \\
\text { Approximately } 625-670^{\circ} \mathrm{C} \text { and } 7-9 \\
\text { kbar }\end{array}$ & Eocene \\
\hline & Extension & & 19.8-25.5 My \\
\hline \multirow[b]{2}{*}{$\begin{array}{c}\text { Ring et al., } 2007 \\
\text { South of Menderes } \\
\text { Massif }\end{array}$} & Menderes Nappes, Ören Nappe & & $\begin{array}{l}\text { Apatite fission-track dating } \\
\text { 18-28 My, 31-42 My }\end{array}$ \\
\hline & $\begin{array}{l}\text { Menderes Nappes Cycladic blueschist unit } \\
\text { Ören Nappe }\end{array}$ & & $\begin{array}{l}\text { Zircon fission-track dating } \\
\text { 29-31 My } \\
\text { 30-33 My } \\
93 \mathrm{My} \text { and } 129 \mathrm{My}\end{array}$ \\
\hline
\end{tabular}




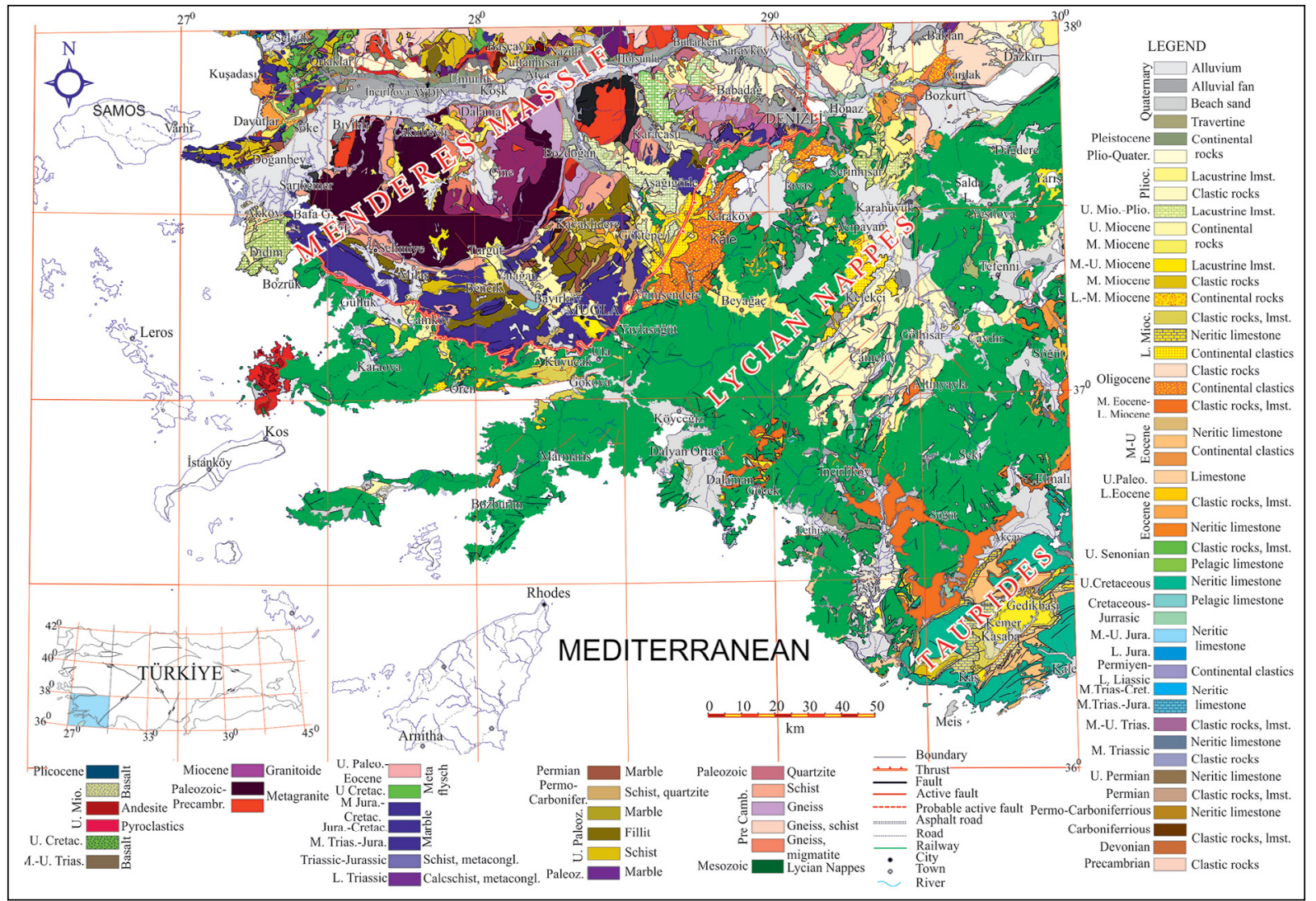

Figure 3- Simplified geological map of the SW Anatolia (simplified from Konak and Şenel, 2002).

2000; Sözbilir, 2002; Bozkurt, 2003) (Figures 4, 5). Some researchers associated the folds with the N-S extensional regime (Seyitoğlu et al., 2000; Sözbilir, 2001, 2002; Çemen et al., 2006), while some others does with the N-S compressional regime (Y1lmaz et al., 2000; Gürer et al., 2009, 2013; Özburan and Gürer, 2012).

The youngest basins of western Anatolia are approximately E-W oriented, long and narrow (several $\mathrm{km}$ wide, tens of $\mathrm{km}$ long), asymmetrical, and generally arcuate (arc-shaped). One margin of each basin is characterized by steep topography associated with surface ruptures of active faults. Numerous closely spaced high-angle antithetic and synthetic faults developed in the footwall and hanging wall blocks of the basins. The horst and graben type morphology dominates the Western Anatolian landform and controls the major westward-flowing drainage system (Y1lmaz, 2017b).

The faults of E-W oriented grabens cut and offset N-S oriented basins (Koçyiğit et al., 1999; Yılmaz et al., 2000; Sözbilir, 2001,2002; Bozkurt, 2001, 2003; Gürer et al., 2001, 2009, 2013; Westaway et al., 2004; Purvis and Robertson, 2004; Ersoy et al., 2011). Most of the N-S basins are generally observed as hanging basins on neighboring young uplifts. Gördes, Demirci and Selendi basins, for instance, are located in the horst block rising between the Gediz and Simav grabens. In addition, it was determined by the magnetotelluric method that the N-S trending basins in the Gediz Graben were trapped under the graben fill (Gürer et al., 2001, 2002).

E-W-oriented basins can be examined under two groups. The first group of basins (e.g., Simav, Gediz, Büyük Menderes) began to develop by a detachment fault and then continued evolving by high-angle antithetic and synthetic normal or oblique faults. Faults limiting the second group of basins (e.g., Bakırçay, Kütahya, Küçük Menderes, Gökova) are high-angle normal or oblique faults.

The basin fills are mainly terrestrial clastic deposits. The sequence, which starts with coarse clastics at 

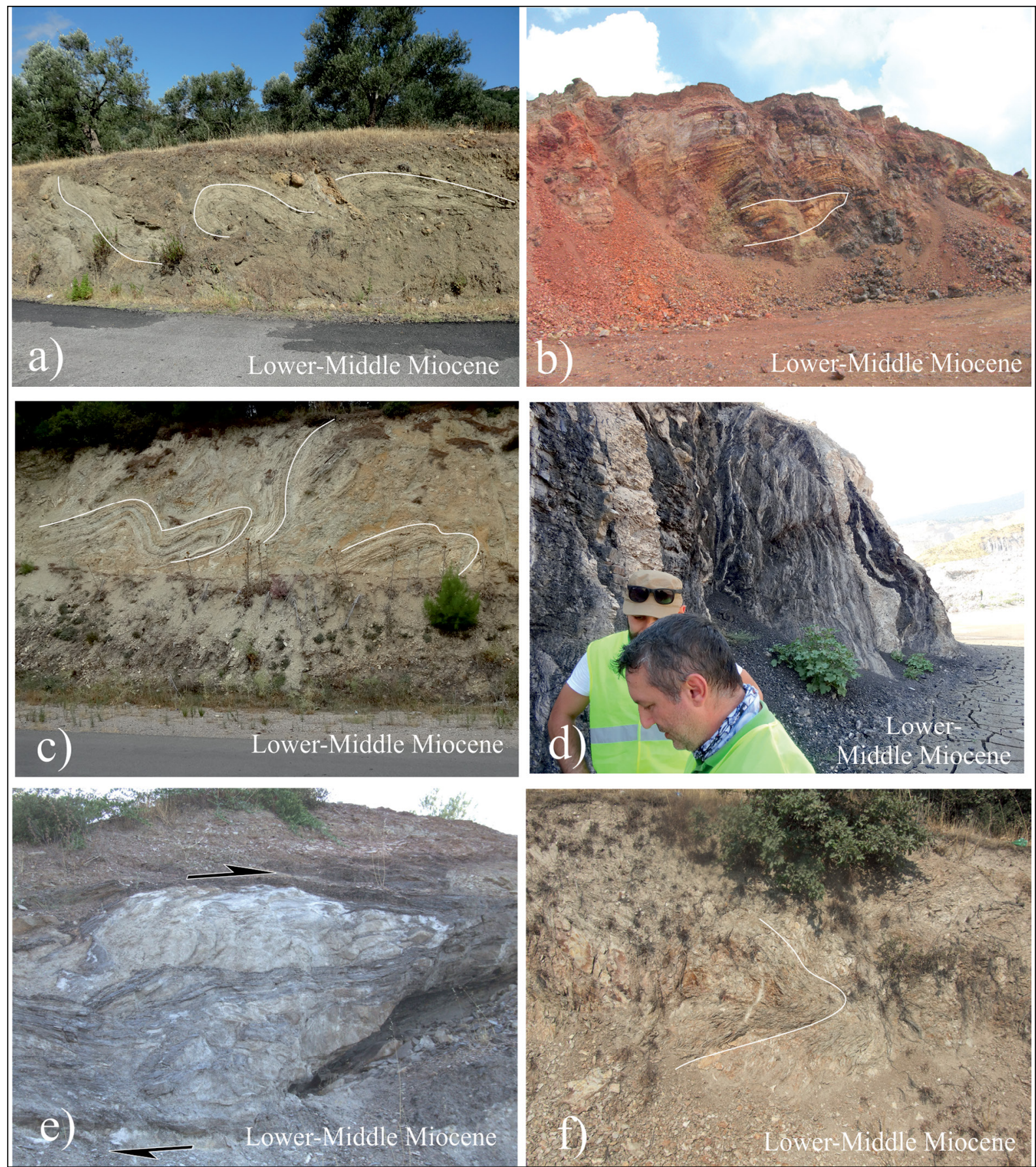

Figure 4- Examples of folds observed in Neogene successions in different parts of Western Anatolia; a) an overturned folding in the Küçükkuyu formation in the Bahçedere village (Edremit) road cut ( $\left.39^{\circ} 590685 \mathrm{~N} / 26^{\circ} 621073 \mathrm{E}\right)$, b) a recumbent fold in the Tunçbilek formation in the Seyitömer coal pit (39 $\left.35^{\prime} 12,28^{\prime \prime} \mathrm{N}, 29^{\circ} 53^{\prime} 04.40^{\prime \prime} \mathrm{E}\right)$, c) examples of overturned and recumbent folds developed in the LowerMiddle Miocene succession in the east of Bergama (39 $\left.12^{\prime} 14.4^{\prime \prime} \mathrm{N}, 27^{\circ} 40^{\prime} 46.6^{\prime \prime} \mathrm{E}\right)$, d) vertical bedding in the Middle Miocene aged succession in the Soma Kisrakdere coal pit ( $\left.39^{\circ} 6^{\prime} 41,5^{\prime \prime} \mathrm{N}, 27^{\circ} 34^{\prime} 2,27^{\prime \prime} \mathrm{E}\right)$, e) tectonic lens structure developed by compression in the Lower-Middle Miocene succession north of Ortaklar (37 $56^{\prime} 19,73^{\prime \prime}$ N, $28^{\circ} 16^{\prime} 59,98^{\prime \prime}$ ) and f) recumbent folding developed in the Lower-Middle Miocene unit in the north of Nazilli $\left(37^{\circ} 58^{\prime} 36,57 \mathrm{~N}, 27^{\circ} 37^{\prime} 21,20 \mathrm{E}\right)$. 

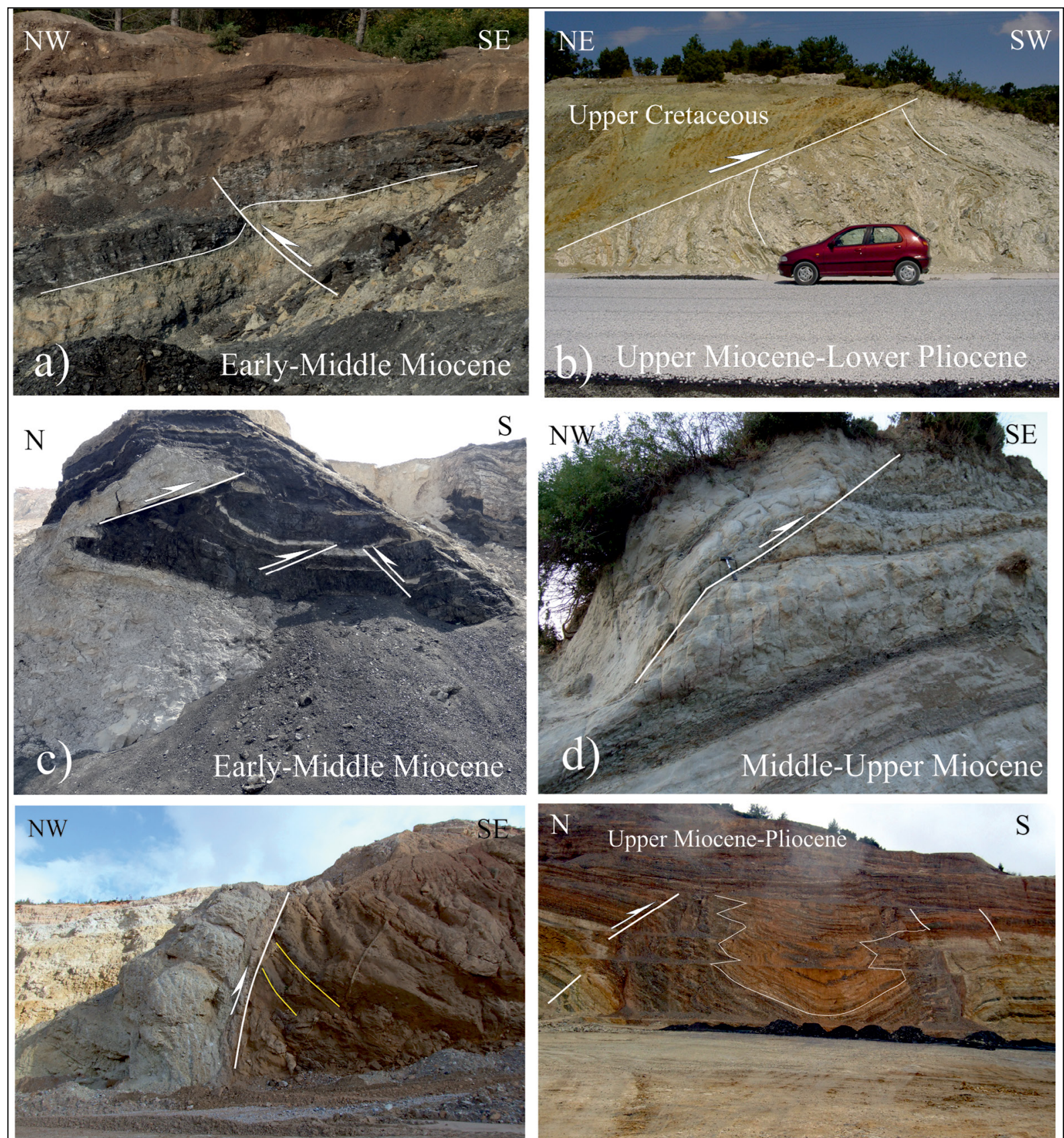

e) Upper Miocene-Pliocene

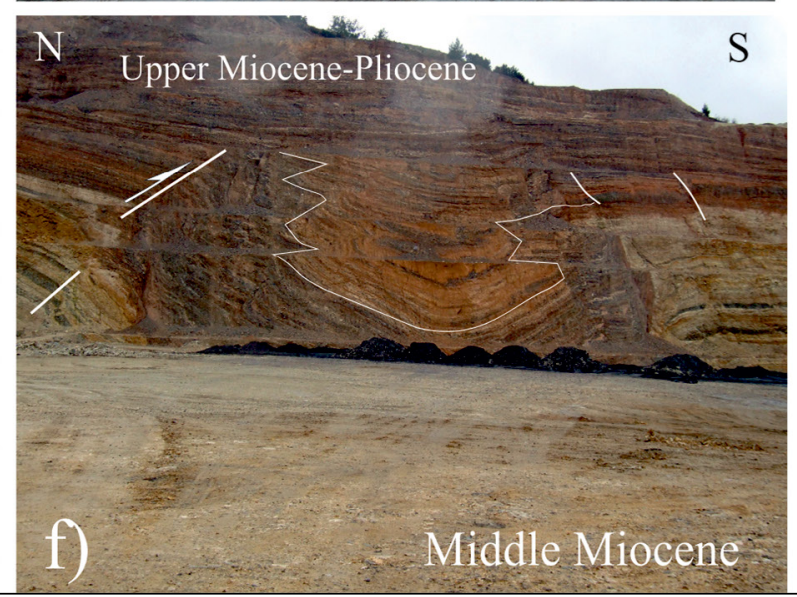

Figure 5- Examples of reverse faults observed in Neogene successions in different parts of Western Anatolia; a) a reverse fault observed in the Lower-Middle Miocene succession in the Çırpıköy coal pit, north of Kazdağ (39 799565 N/ $27^{\circ} 335935$ E), b) ophiolite slice of the Tavşanlı Zone thrusted over the Emet formation on the Kütahya-Eskişehir highway $\left(39^{\circ} 29^{\prime} 10,25^{\prime \prime} \mathrm{N}, 30^{\circ} 02^{\prime} 41,17^{\prime \prime} \mathrm{E}\right)$, c)

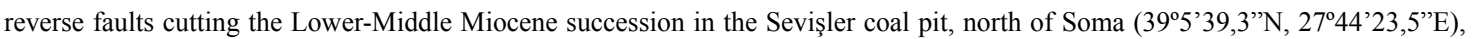
d) a reverse fault cutting the Middle-Upper Miocene succession in the southeast of Kuşadas $\left(37^{\circ} 49^{\prime} 46,10^{\prime \prime} \mathrm{N}, 27^{\circ} 17^{\prime} 29,48^{\prime \prime} \mathrm{E}\right)$, e) A reverse fault developed in the Late Miocene-Pliocene aged Yatağan formation in the Tınaz Coal pit at the south of Yatağan (35 $606117, \mathrm{~N} / 41^{\circ} 21810 \mathrm{E}$ ) and f) reverse faults and synclinal fold structure developed in the underlying Sekköy and overlying Yatağan formations, in the Tinaz coal pit $\left(35^{\circ} 4121395 \mathrm{~N} / 60^{\circ} 7818 \mathrm{E}\right)$. 
the basin margins, continues with fine-coarse clastic alternations in the basin interior. The basin fill is generally horizontal; however folding and back tilting associated with stretching toward faults are observed (Sözbilir, 2002; Bozkurt and Sözbilir, 2004). Actual rivers such as Bakırçay, Gediz and Büyük Menderes flow through these basins.

The relations and origins of these two groups of basins in the region have long been controversial. In this study, based on our own observations and literature knowledge, brief information about the underlying structural units and Neogene-Quaternary basins will be given, and debates on their relationships and origins will be discussed. The readers can obtain detailed information about the basins from the related resources.

\subsubsection{Edremit Basin and the Surroundings}

Edremit Basin, the largest basin in Northwest Anatolia, extends into the sea towards the west by expanding (Figure 6). While the northern margin of the basin is steeper, linear, and distinct, the southern margin is gently inclined, indented, and indistinct. The structural and geometrical features of the basin indicate that it is a transtensional basin (Gürer et al., 2014, 2016. Koçyiğit and Gürboğa, 2021).
A basinal sequence represented by lacustrine deposition in the Early-Middle Miocene is present around Edremit. This clastic sequence consisting of bituminous shale, tuff, mudstone, sandstone, and limestone, which are mainly the products of lacustrine depositions, outcropping in the Küçükkuyu and the surroundings at the north and in the Ayvalık and its surroundings at the south are defined as Küçükkuyu Formation. The unit, mainly grey, brown, and green colored, is thin- to medium-bedded and is monotonous in terms of succession features (Gürer et al., 2016).

The Küçükkuyu formation was probably deposited in interconnected lacustrine environments in the central and eastern parts of the Biga Peninsula (Ayvalık, Küçükkuyu, Bayramiç, Çan, Yenice, Kalkım etc.). The sequence was developed mainly on the Çetmi mélange in the south of Kazdağ and rarely on the Asos volcanics. The succession, which started with conglomerate and sandstone alternation, then continued with alternation of sandstone, siltstone, and mudstone. Considering the lithology, facies distribution, geometry and structural position of the formation, it can be inferred that the basin margin rests against a high-angle rim and deepens from east to west (Y1lmaz and Karacik, 2001). The formation, which is partially deformed in all areas where it outcrops, is the

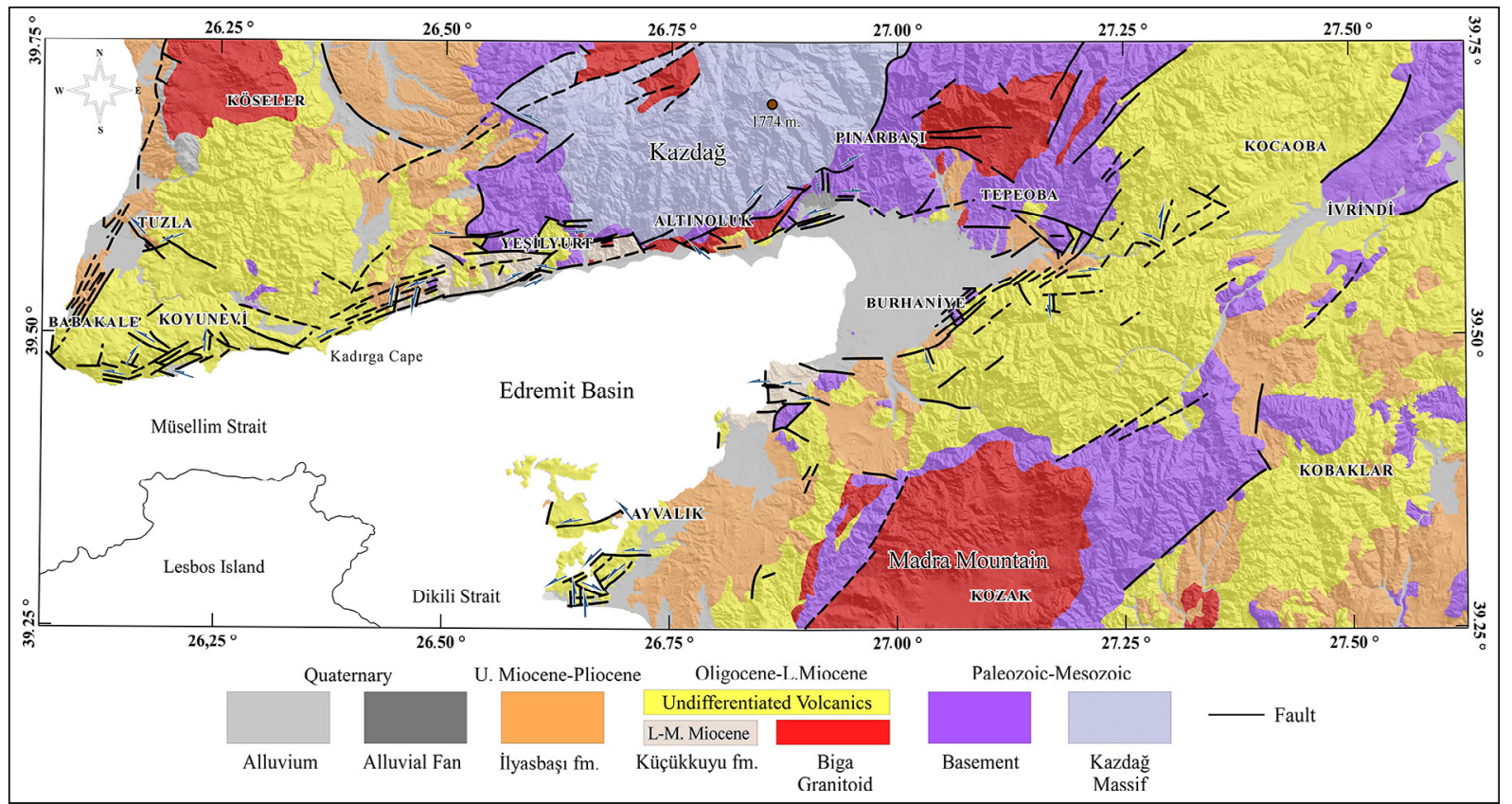

Figure 6- Simplified geological map of the Edremit Basin and its surroundings (adapted from Emre et al., 2012 (Gürer et al., 2016)). 
equivalent of Early-Middle Miocene-aged lacustrine deposits widely exposed in Western Anatolia. The deformation developed as folding and faulting, and examples of overturned folds were observed as well as open folds (Figures 4a, 5a).

\subsubsection{Kütahya Graben and the Surroundings}

Kütahya and its surrounding area is one of the regions where the compressional and extensional system is well observed, exhibiting extensive Neogene-Quaternary successions, folds, reverse faults, uplifts and basin systems. The most prominent morphological element of the region is the Kütahya Graben with an approximately $\mathrm{N} 65^{\circ} \mathrm{W}$ orientation, 50 $\mathrm{km}$ length and 2-8 km width (Figure 7). The northern margin of this asymmetrical graben is indistinct and irregular, while the southern margin is more distinct, linear and high-angled. The boundary between the Graben and the Yellice horst located in its south is a normal fault zone with a left lateral component. Small-medium-sized alluvial fans developed between the horst and the graben.
To the north of the Kütahya graben, two NE-SW trending basins, Seyitömer and Sabuncupınar basins, extend. Seyitömer Basin is approximately $25 \mathrm{~km}$ long and $14 \mathrm{~km}$ wide. Both basins are filled with a sequence consisting of two successions belonging to the LowerMiddle Miocene and to the Pliocene. Stratigraphic and sedimentologic data indicate the presence of a significant angular unconformity between these two successions. The initial fillings of the basins are different from each other. Beke Formation (Lower Miocene) consisting of conglomerate, sandstone and siltstone and Tunçbilek Formation (Lower-Middle Miocene) consisting of coal seams intercalated with conglomerate, sandstone, siltstone, marl, claystone, tuff, limestone form the main filling of Seyitömer Graben. The Sabuncupınar Basin with an approximate $\mathrm{N} 30^{\circ}-35^{\circ} \mathrm{E}$ orientation is filled with volcanics mainly composed of tuff and pyroclastics. Different fillings of these two parallel basins suggest that Karaöz Uplift located between them was a significant barrier in the Early-Middle Miocene period (Özburan, 2009; Özburan and Gürer, 2012).

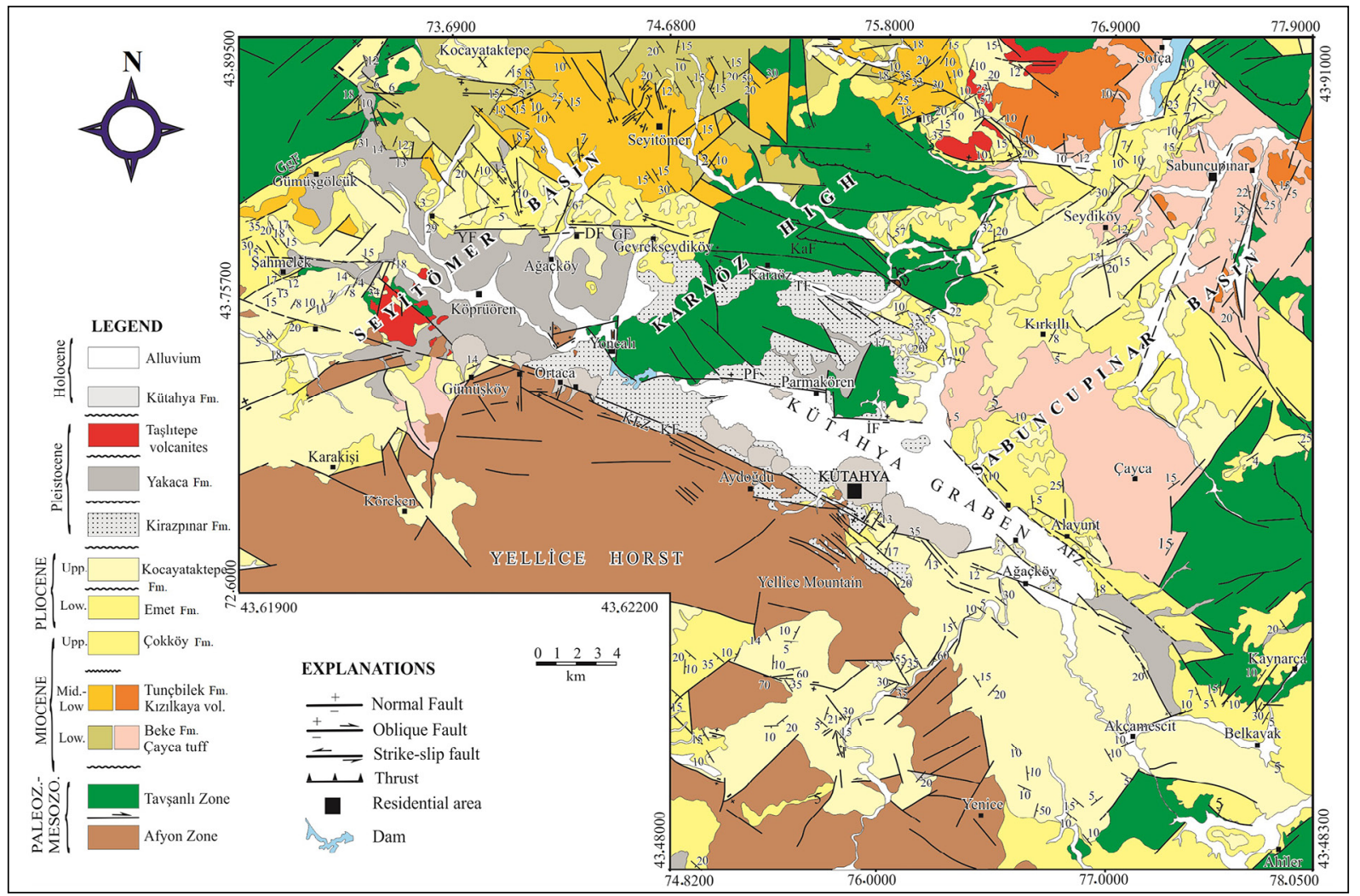

Figure 7- Geological map of the Kütahya graben and its surroundings (Özburan, 2009; Özburan and Gürer, 2012). 
The common cover of these two basins and uplift is Late Miocene-Pliocene aged sequence that starts with an angular unconformity on the first succession in Seyitömer Basin and a parallel unconformity in Sabuncupinar Basin. The first unit of the sequence is the Çokköy Formation, which starts with conglomerate and later changes into alternating sandstone, siltstone and claystone. The overlying Emet Formation begins with an alternation of sandstone and claystone at the bottom and continues with mudstone, limestone and marl.

\subsubsection{Bakurçay Basin and the Surroundings}

Bakırçay Basin is a NE-SW trending, bow-tie shaped basin with a length of approximately $60 \mathrm{~km}$ and a width of $5 \mathrm{~km}$ (Figure 8). In the west of the basin, which has an asymmetrical morphology, the northern margin is steeper and linear than the southern margin. However, there is an opposite morphology in the east of the basin. The basin is located in a tectonically complex region where the $\mathrm{N}-\mathrm{S}$ extensional regime of the Aegean extensional system and the NESW trending North Anatolian Fault System (NAFS) intersect. Therefore, it is accepted that these two factors concurrently control the neotectonic deformation of the region (e.g., Taymaz et al., 1991; Y1lmaz et al., 2000; Pfister et al., 2000; Bozkurt, 2001a, b, 2003; Gürer et al., 2006, 2016; Yılmaz, 2017).

Three successions around the basin, separated by unconformable contacts between them, are as follows: The Early-Middle Miocene aged Dikili group, the Late Miocene aged Zeytindağ group and the PlioQuaternary aged Bergama Basin fill. Early-Middle Miocene aged terrestrial sediments and the volcanics interfingering with them at all levels are located in the north and south of the basin. The sediments consist

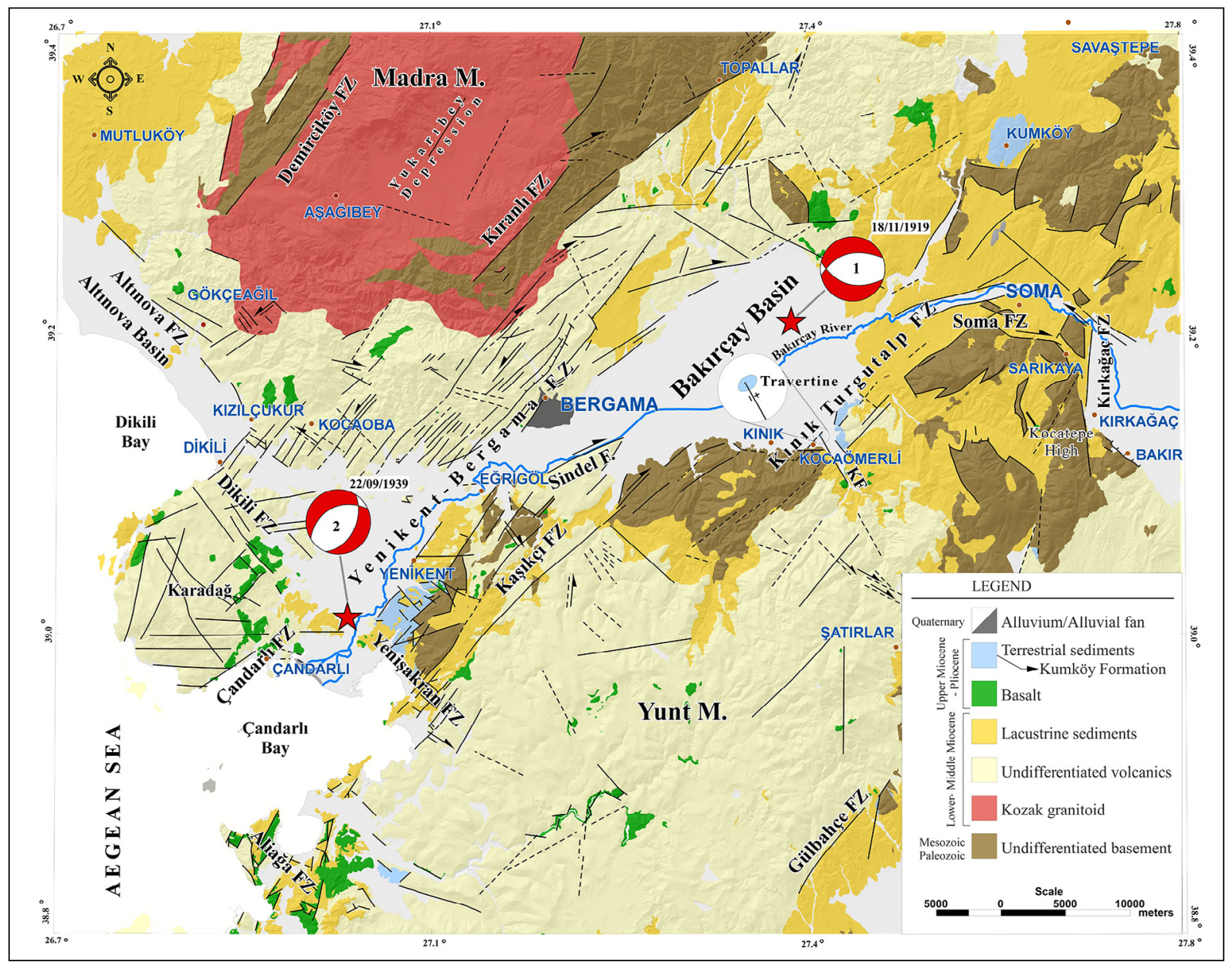

Figure 8- Simplified geological map of the Bakırçay Basin and its surroundings (modified from Konak, 2002). Two earthquake mechanisms in Bakırçay Basin are taken from Paradisopoulou et al. (2010) (Sangu et al., 2020). 
of sandstone, mudstone, marl and shale alternations deposited in a lacustrine environment. Lacustrine deposits outcropping in NE-SW direction, especially in the east of the Çandarl1-Bergama line, exhibit widespread outcrops in the east of Bakırçay Basin and around Soma. In the sequence known as the Dikili group, open and closed folds and reverse faults have sporadically developed (Figures 4c, 5c).

\subsubsection{Gediz Graben and the Surroundings}

The Gediz Graben, one of the most developed grabens in Western Anatolia(Figure 9), has been studied in detail by many researchers in recent years (e.g., Cohen et al., 1995; Emre, 1996; Seyitoğlu and Scott, 1991, 1996; Koçyiğit et al., 1999; Y1lmaz et al., 2000; Sözbilir, 2001; Işık et al., 2003; Çiftçi and Bozkurt, 2008, 2009; Öner and Dilek, 2011, 2012, 2013). The $140 \mathrm{~km}$ long and 10-15 km wide Gediz Graben, which has an arc-shaped geometry, is asymmetrical and its southern margin is steeper and more seismically active. Most of the graben fill outcrops around the southern margin. There are sedimentary basins developed in two different directions around the Gediz Graben. The NE-SW trending and Early-Middle Miocene aged ones are filled with younger clastic, volcanoclastic and volcanic rocks. The Gediz Graben, on the other hand, is E-W trending and is mainly filled with clastic rocks (Yllmaz et al., 2000; Purvis and Robertson, 2004; Ersoy and Helvac1, 2007; Ersoy et al., 2010; Öner and Dilek, 2011, 2013).

The NE-SW trending major basins, mostly bounded by high-angle normal faults with strike-slip components, are Gördes, Demirci, Selendi, UşakGüre Basins (Yılmaz et al., 2000; Bozkurt, 2003; Ersoy et al., 2010). Gördes, Demirci and Uşak-Selendi basins are filled with a succession dominated by Early-Middle Miocene aged terrestrial clastic rocks, unconformably overlying the metamorphic rocks of the Menderes Massif and the İzmir-Ankara ophiolites. The stratigraphic and structural features of these basins have been introduced in detail in recent years (e.g., Seyitoğlu and Scott, 1994, Seyitoğlu et al., 1994; Seyitoğlu and Scott, 1996; Y1lmaz et al., 2000; Purvis and Robertson, 2004; Ersoy et al., 2011).

The faults generating the Gediz Graben cut the NESW trending basins and slightly offset in a lateral sense (Y1lmaz et al., 2000; Gürer et al., 2001). As a result, NE-SW trending basins remained as hanging grabens on the footwall blocks. This relationship indicate that NE-SW trending grabens were continuous before the development of the Gediz Graben.

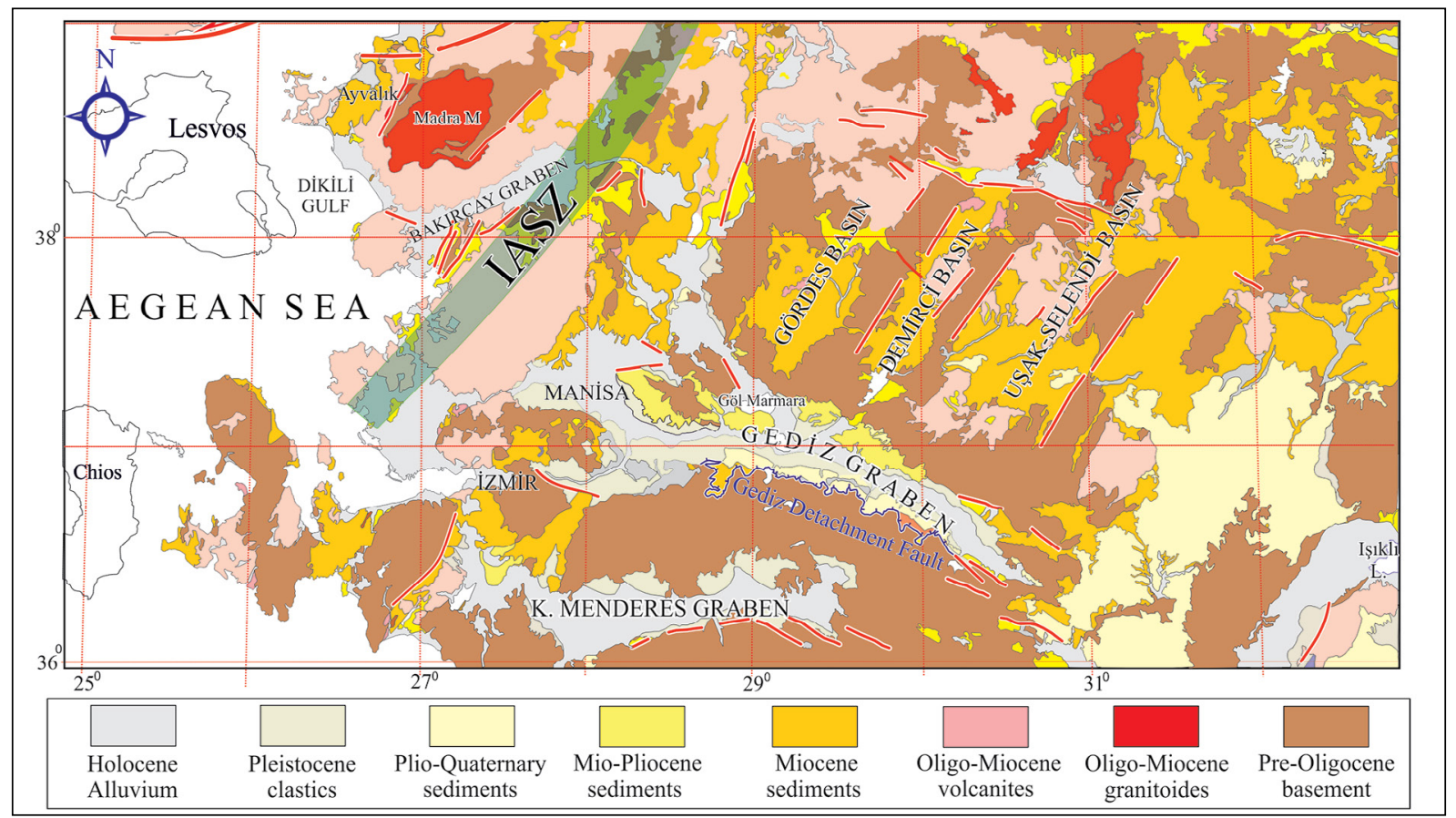

Figure 9- Simplified geological map of the Gediz graben and its surroundings (modified from Konak, 2002). IASZ: İzmir-Ankara Suture Zone. 


\subsubsection{Büyük Menderes Graben and the Surroundings}

Büyük Menderes Graben bounded by the Menderes Massif from the north and south, is a $140 \mathrm{~km}$ long and 2.5-14 km wide graben with an arc-shaped structural geometry. The Graben extends approximately in an E-W direction until Ortaklar, and extends mainly in a NE-SW direction from there to the west (Figure 10). The northern margin of the graben is bounded by the linear mountain frontage of the Mount Aydin, which rises steeply from $50 \mathrm{~m}$ up to $1750 \mathrm{~m}$, while the southern margin has a lower topography. These morphology and structural features indicate that the Büyük Menderes Graben is an asymmetrical graben (Gürer et al., 2009; Yılmaz, 2017a).

Two main rock groups, a basement consisting of the Menderes Massif and a Neogene-Quaternary sedimentary cover up to $2.5 \mathrm{~km}$ thick, are distinguished in and around the Büyük Menderes Graben. Interpretation of the data obtained from the cover units reveals the existence of three non-systematic lithostratigraphic units named A, B and C (Gürer et al., 2009). These three units outcrop on the northern margin of the graben, while units A and C outcrop on the southern margin. The relationship between the successions and the underlying metamorphic rocks is generally tectonic. Different tectonic processes produced diverse fault systems and basins in the region during the Neogene-Quaternary period.

The graben and its surroundings are cut by various fault groups ranging from oblique faults to high and low angle normal faults. Conjugate faults mainly strike NE and NW directions, while most of the normal faults strike E-W direction. Two fault systems have developed in the region: 1) Approximate NE and NW oblique faults adjacent to Unit A, 2) E-W trending faults adjacent to $\mathrm{B}$ and $\mathrm{C}$ units. The second group of faults can be subdivided into a) low-angle Büyük Menderes Detachment Fault with E-W direction and b) synthetic and antithetic en echelon normal faults (Y1lmaz, 2017a).

The geological map of the Büyük Menderes Graben shows the existence of two structural basin systems of different ages and directions. The first

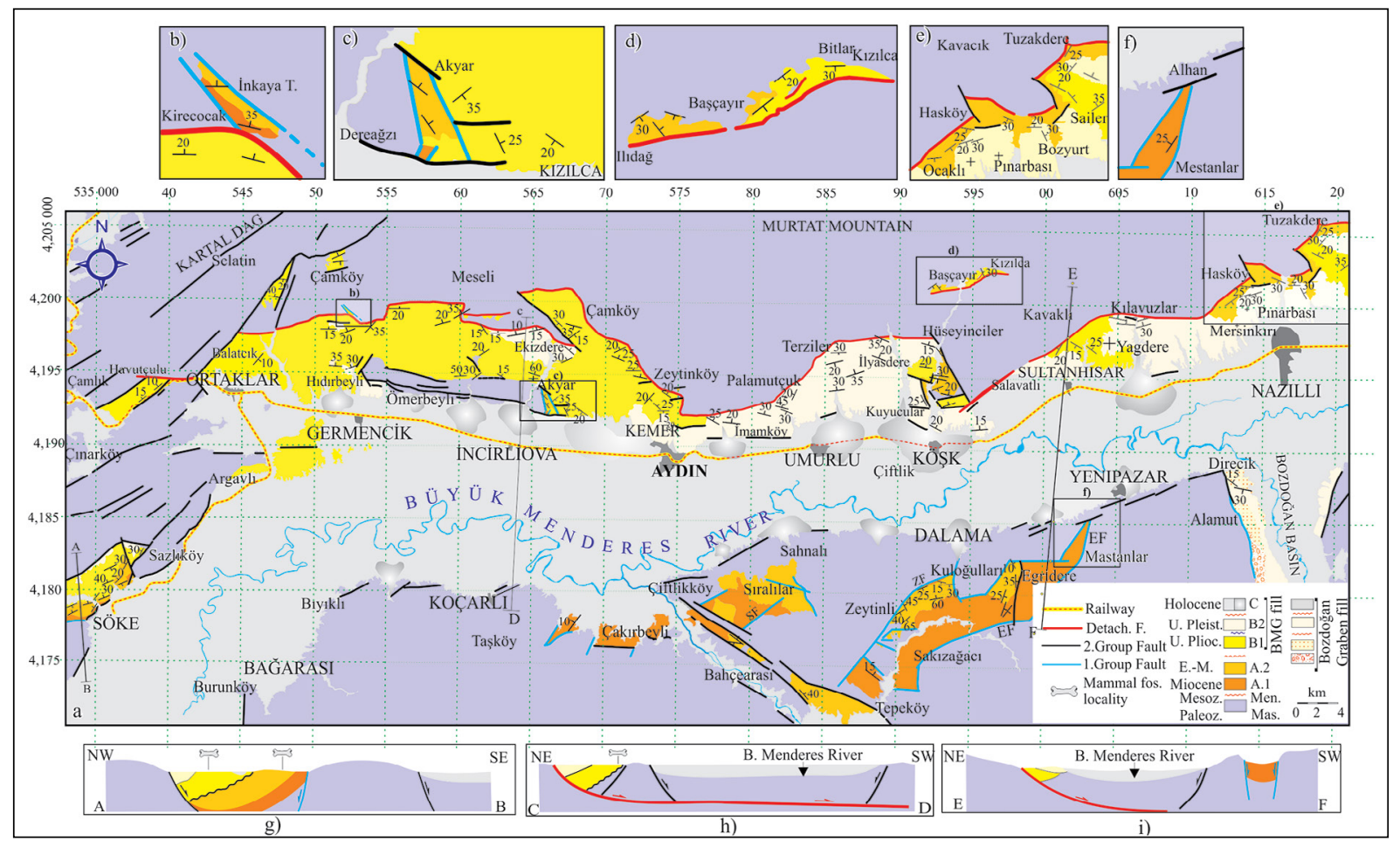

Figure 10- a) Geological map of the Büyük Menderes graben. BMDF: Büyük Menderes Detachment Fault, EF: Eğridere Fault, ZF: Zeytinli Fault, SF: Siralılar Fault, b), c), d), e) and f) show the locations of the extended maps given in Figure 10. A-B, C-D and E-F represent the section lines given in Figure 10a (Gürer et al., 2019). 
system is represented by N-S oriented structural depressions filled with Lower-Middle Miocene continental sediments. The second system cuts the preceding one and is represented by the E-W trending Büyük Menderes Graben filled with Plio-Quaternary terrestrial deposits. The synthesized data indicate that two different basin formations around the Büyük Menderes Graben, which developed in different structural environments, resulting from two successive and different tectonic regimes.

The Lower-Middle Miocene fillings (Unit A) of the NW and NE trending basins have been deformed in places by folds and reverse faults (Figures 4e, $\mathrm{f}, 5 \mathrm{~d})$. It has been suggested that folds and oblique faults correspond to a N-S compression in the region (Y1lmaz et al., 2000; Gürer et al., 2009). It has been proven by fault kinematics studies that the N-S trending Bozdağan and Karacasu Basins, located in the south of the Büyük Menderes Graben, were deformed by N-S compression in Miocene and Early Pliocene (Ocakoğlu et al., 2014).

\subsubsection{Gökova Graben and the Surroundings}

Four groups of basins with different development periods and directions are present around the Gulf of Gökova, which is located in the southernmost part of the Western Anatolian Extensional Region. It has been suggested that the formation of the basins occurred in different structural environments and resulted from different consecutive tectonic regimes (Gürer and Yilmaz 2002; Gürer et al., 2013). Two different basement units, Lycian Nappes and Menderes Massif, coexist in the region (Figure 11). Gökova is a critical region for a better understanding of the transition from the compressional system to the extensional system.

The first group is represented by a NE-SW trending basin (Kale-Tavas Basin) filled with Oligocene-Lower Miocene shallow marine-terrestrial sediments. KaleTavas Basin extends in the E-W direction to the north and south of the Gulf of Gökova and NE-SW direction between the Gulf of Gökova and Denizli. The sequence of the Kale-Tavas Basin unconformably overlies the crystallized limestone and marbles of the Lycian nappes in the north of the Gökova Gulf, and the ophiolitic basement of the Lycian nappes around Acipayam, Denizli and Burdur in the south and east of the Gökova Gulf. The basin succession, which starts with a thick conglomerate, sandstone alternation at the base, and continues upward with conglomerate, sandstone and mudstone alternations, ends up with reefal limestone lenses.

The NE and NW trending structural depressions (Eskihisar and Tinaz Basins) in the second group are filled with Lower-Middle Miocene terrestrial deposits. Both of these basins bounded by oblique faults are geometrically L-shaped. In both basins, the successions start with conglomerate and sandstone alternation at the bottom (Turgut Fm.) and end up with sandstone, mudstone and marl alternation containing lignite intercalations (Sekköy Fm.). Fossils obtained from the limestones provide a Middle Astarasian age (Middle Miocene, 14 My) (Atalay, 1980; Gürer and Y1lmaz, 2002).

The third group of basins in the region is the Yatağan Basin, which is located between Yatağan district and Gökova Bay. The NW-SE trending basin is $30 \mathrm{~km}$ long and $10 \mathrm{~km}$ wide, with unclear borders and geometry. The basement of the basin is the Menderes Massif in the north and the Lycian nappes in the south. The basin fill consists of brown, poorly sorted, thick-bedded alluvial conglomerate at the bottom, passes upwards into grayish-brown sandstone and mudstone, and ends up with light grey-white clayey limestone intercalations. Limestone and marl lenses, tuff intercalations and travertine are present at different levels of the succession. The succession is $300-500 \mathrm{~m}$ thick, and the red-colored beds provides a mammal fauna in the Muğla region representing the time interval spanning from the Middle Astaracian to the Turolian (Atalay, 1980). The basin has been interpreted as an intermountain basin developed without significant tectonic control (Gürer et al., 2013). Reverse faults were observed in places in the Miocene and Pliocene successions in the region (Figures 5e, f). The fourth group of basins in the Gökova region are Muğla, Paşapınarı, Yeşilyurt, Ula and Gökova Basins. These basins are filled with block-gravel, pebbly sand, sand and clays of the alluvium, colluvium and alluvial fan deposits. The sequence consists of marine sediments in the Gulf of Gökova. Muğla and Gökova basins are located at the altitudes of $650-700 \mathrm{~m}$ and $850 \mathrm{~m}$ respectively. 


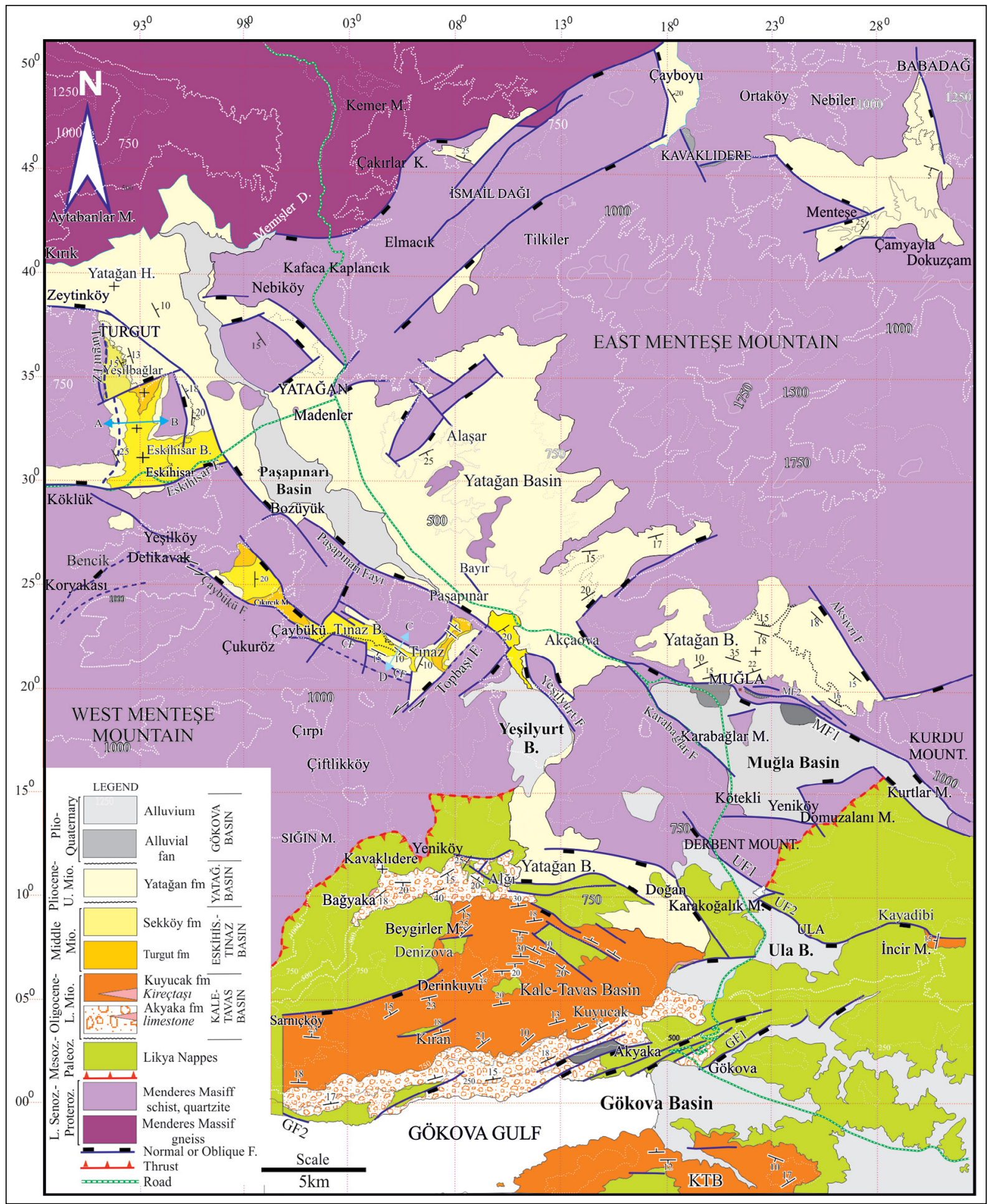

Figure 11- Geological map of the Gulf of Gökova and its surroundings (Gürer et al., 2013). 
Çameli and Eşen Basins, placed within the FethiyeBurdur Fault Zone in SW Anatolia, are also continental basins developed in the Neogene-Quaternary period. Compressional deformational structures were also observed in these basins bounded by oblique faults. Detailed information about these basins can be found in related studies (e.g., Alçiçek et al., 2004, 2005; Elitez and Yaltırak, 2014).

\section{Discussions}

In the evaluation of the above-mentioned studies on the Neogene-Quaternary basins in Western Anatolia, it is seen that there are disagreements, especially about the onset of the extension, the continuous or discontinuous nature of the extension, and the origin and evolution of the basins. In this section, the discussions about the compression and extension phases in the region will be briefly summarized.

The Late Cretaceous period marks the initiation of a convergent tectonic regime in and around Turkey and is particularly characterized by the emplacement of ophiolite nappes. These nappes were moved to large carbonate platforms that began to collapse by the onset of settlement (Y1lmaz, 2017a,b). It has been suggested that the ophiolite slices derived from the closure of the northern branch of Neotethys, which was located between the Sakarya Continent and the Tauride-Anatolide continent in the Late CretaceousEocene interval, progressed from north to south as nappes (Şengör and Yılmaz, 1981; Özgül, 1976, 1984; Hayward and Robertson, 1982; Dixon and Robetson, 1984; Şengör et al., 1985; Collins and Robertson, 2003; Okay, 2001; Ten Veen et al., 2009; Nemec et al., 2018). The nappes emplaced on the Taurides by moving over the Menderes Massif caused the deformation of the Taurides and the formation of thick nappe slices. Compression and the nappe slices have caused the continental crust in Western Anatolia to be thickened (Y1lmaz, 2017a).

From the Oligocene period, on the other hand, the first uplift of the metamorphic complexes of the Aegean occurred and was partially exposed (Lacassin et al., 2007). Different opinions have been suggested on the uplift time and mechanism of the massifs, especially the Menderes Massif, in the region. Some researchers have claimed that the Menderes Massif was uplifted by compression in the OligoceneMiddle Miocene interval and by the N-S extension after the Late Miocene or Plio-Quaternary (Yilmaz et al., 2000; Erkül et al., 2005a, b; Gürer et al., 2009, 2013). According to these researchers, during the Late Oligocene-Early Miocene, the Menderes Massif and all Western Anatolia underwent a compressional deformation in N-S direction. In addition, it has been suggested that the Thrace Basin and the Balkans were compressed in the NW-SE direction during the Late Oligocene-Early Miocene and thus folded (Erbil et al., 2021). As a result of this compression, the entire region was shortened, folded, imbricated, and thickened. This was followed by an extensional phase, probably due to the orogenic collapse (Seyitoğlu et al., 2004) or the rollback mechanism in the South Aegean Trench (Bozkurt, 2003; Gürer et al., 2009, 2013; Y1lmaz, 2017a,b). Some researchers have suggested that the massif has been uplifted as an extensional core complex since the Late Oligocene (e.g., Ring et al., 2003; Seyitoğlu et al., 2004; Emre and Sözbilir, 1997; Sözbilir, 2005).

Various studies have been carried out associating the development of the basins in Western Anatolia with the uplift of the Menderes Massif (e.g., Gessner et al., 2001a; Ring et al., 2003; Seyitoğlu et al., 2004; Seyitoğlu and Işı1k, 2015). However, researchers working on the Menderes Massif have suggested different point of views about the geometry and movement directions of the nappes in the massif (Table 1). The northward movement of the upper plate has been suggested as pre-Alpine (Gessner et al., 2001b), pre-Eocene (Regnier et al., 2003), Eocene (Rimmele, 2003), Late Oligocene-Early Miocene (Bozkurt and Park, 1997; Seyitoğlu et al., 2004; Bozkurt et al., 2006).

Most of the researchers suggested that the Menderes Massif was uplifted by the core complex mechanism associated with the N-S directional extension in western Anatolia during the Late Oligocene-Miocene period. In general, metamorphic core complexes (MCCs) are interpreted as domal structures caused by ductile to brittle, high-stress metamorphic rocks extending under a high-stress detachment fault that undergo tens of kilometers of displacement in response to lithospheric extension. In such structures, 
it has been argued that stress is the driving force that regulates uplift (Searle and Lamont, 2019).

Searle and Lamont (2019) stated that various core complexes such as the Himalayan, Karakoram and Pamir domes, completely occurred in compressional environments and are not related to the lithospheric extension. They suggested that many MCCs previously thought to have formed due to extension are related to compressional tectonics. According to the authors, low-angle normal faults due to regional Aegean extension previously generated contraction folds and metamorphic fabrics associated with crustal shortening and thickening in Naxos.

The exhumation mechanism of the Menderes Massif during the Late Oligocene-Early Miocene is a controversial issue. Has the uplift of the massif been caused by low-angle thrusts or normal faults commonly defined in the massif? Otherwise, considering its internal structure consisting of nappe slices where there is no consensus on the movement directions and times; the idea that the Menderes Massif may also be a compressional metamorphic complex, just as in the Himalaya, Karakoram, Pamir and Naxos examples proposed by Searle and Lamont (2019) becomes more likely.

Debates on the continental collision that started in the Late Cretaceous in Western Anatolia and the duration of the subsequent compression have been continuing. According to some researchers, the Lycian nappe stack advanced southward during the Early Miocene and finally emplaced on the Lower Miocene basin fill of the Antalya Basin prior to the Late Miocene (Okay, 1989; Collins and Roberston, 1998; Y1lmaz et al., 2000, Gürer et al., 2009, 2013). According to some other researchers (Şengör, 1982; Hayward, 1984; Şengör et al., 1985), the compression lasted in the Western Taurides in the south and along the frontal thrust zone of the Lycian Nappes until the Late Miocene. It is claimed that the Taurides advanced over the younger Mediterranean basins in the south by carrying the Lower-Middle Miocene marine sediments on its back and started to uplift (Y. Yılmaz, personal communication). According to Seyitoğlu et al., (1992), on the other hand, the nappe movement from the Early Miocene in the north (in
Isparta) until the Late Miocene in the south and the west was attributed to the gravity sliding rather than N-S directional compression. This hypothesis was later supported by Collins and Robertson (1998), who suggested that the compressional shear zone at the base of the Lycian allochthon was reactivated as an extensional detachment during the Late OligoceneEarly Miocene extensional collapse.

The fluvial and lacustrine sediments, which were commonly developed in the Early Miocene, rest on the high-grade metamorphic rocks of the Menderes Massif, occasionally with an unconformable contact. The outcrops of the Menderes Massif observed from the northern margin (Demirci-Simav region) to the southern margin (Çine-Yatağan region) suggest that the main uplift of the Menderes Massif that resulted the exhumation of middle and lower crustal rocks occurred just before the Early Miocene, and removed approximately $20 \mathrm{~km}$ of material from the massif (Y1lmaz et al., 2000a,b). Metamorphic and plutonic rocks and the minerals developed under the influence of faulting mechanism in Western Anatolia were dated by different methods, the geological/geodynamic evolution of the region was interpreted, and the plutonic rock emplacement related to the extension, the uplift rate and timing were discussed (Sümer et al., 2020). In addition to detailed structural and geochronological studies in the Menderes Massif, two models have mainly been proposed for N-S trending basins. The first is extensional type basins such as rifts (Figure 12b) (e.g., Görür et al., 1995) or supradetachment basins (Figures 12a, c) (e.g., Lips et al., 2001; Sözbilir et al., 2011; Öner and Dilek. 2013). Low or high-angle normal faults are the main factor causing the stretching in such environments. Supradetachment systems are characterized by significantly higher rates of crustal extension than that in the rift systems (Friedmann and Burbank, 1995). The second model is transtensional or transpressional basins specific to compressional environments. The differences between the N-S and E-W trending basins in Western Anatolia are presented in Table 2.

The Early-Middle Miocene aged basins in Western Anatolia developed on different basement rocks, from the Marmara Region in the north to the Mediterranean in the south. In the southern Marmara, 


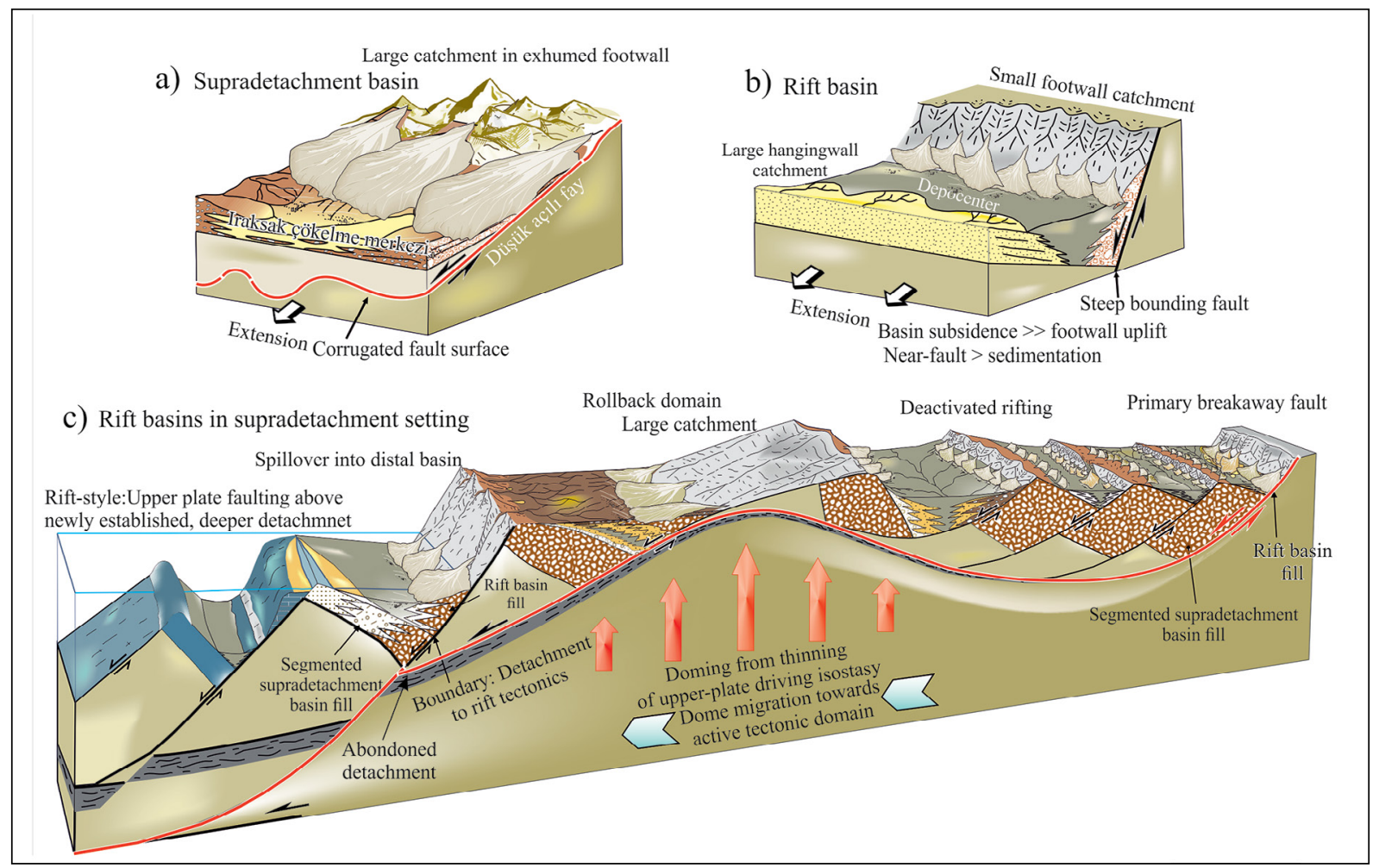

Figure 12- Block diagrams illustrating the characteristics of supra-detachment and rift basins (Modified from Serck et al., 2021).

Table 2- Comparison of the N-S and E-W trending basin characteristics.

\begin{tabular}{|l|l|l|}
\hline & N-S trending basins & E-W trending basins \\
\hline Geometry & Rhomboidal or trough shaped & Curved (arched), graben-half graben \\
\hline Basin fill & Strike slip, oblique normal & Normal, oblique normal \\
\hline Basin symmetry & $\begin{array}{l}\text { Conglomerate, sandstone, marl, limestone } \\
\text { interfingering with volcanics }\end{array}$ & $\begin{array}{l}\text { Conglomerate, sandstone, mudstone with rare tuff } \\
\text { intercalations }\end{array}$ \\
\hline Facies changes & Variable & Generally asymmetric \\
\hline Environment & E-W & N-S \\
\hline Period & Fluvial, alluvial fan, lacustrine & Fluvial, alluvial fan \\
\hline Deformation & Early-Middle Miocene & Plio-Quaternary \\
\hline Basement & Open and closed folds, reverse faults & $\begin{array}{l}\text { Open folds related to the extension, back-tilting, normal } \\
\text { faults }\end{array}$ \\
\hline
\end{tabular}

Gönen and its surroundings (Gürer et al., 2003, 2006), Ayvalık-Altınova Basin (Yılmaz et al., 2000; Sangu et al., 2020), Soma and its surroundings, Urla Basin, Çubukludağ and Kocaçay basins (Genç et al., 2001; Uzel and Sözbilir, 2008; Göktaş, 2020), Seyitömer and Sabuncupınar basins in the northeast of Kütahya (Özburan and Gürer, 2012) are some of them. As can be seen, some of the basins were developed on or around the detachment faults, while others are distributed to the areas where detachment faults are not present. Thus, it is not possible to associate all basins with detachment faults or normal faults.

During the Early Miocene-Quaternary period, Western Anatolia has been approximately compressed in the N-S direction in different periods (Figures 4, 5). Several researchers working in Western Anatolia have displayed folds and reverse faults associated 
with the compression (Koçyiğit et al., 1999; Yılmaz and Karacık, 2001; Kaya et al., 2004; Beccaletto and Steiner, 2005; Bozkurt and Rojay, 2005; Rojay et al., 2005; Erkül et al., 2005a, b; Çiftçi and Bozkurt, 2009).

The main basins that can develop in compressional environments are the foreland basin, piggy-back basin, transpressional or transtensional basins. Considering the geology of the region, N-S trending basins may be related to strike-slip basins, many of whose geological features are given by Nilsen and Sylvester (1995). If the characteristic features of the strike-slip basins are compared with the stratigraphic, sedimentologic, geometric and structural features of the N-S trending basins in Western Anatolia, it is thought that these basins may be pull-apart or transtensional pull-apart basins associated with strike-slip faults (Figure 13). However, detailed studies in the region will provide new approaches to the origins of N-S trending basins.

\section{Conclusions}

The main results obtained in the light of the arguments regarding the Neogene-Quaternary geology of Western Anatolia are listed below.

1- Although many studies have been carried out on the Menderes Massif, there are still debates about the exhumation age and mechanism of the massif. The internal structure of the Menderes Massif, consisting of nappe stacks, strengthens the idea that the massif may be a compressional core complex as shown in the Himalayan, Karakoram, Pamir and Naxos massifs. In the light of the data discussed in this article, it is possible to figure out this problem with a problemfocused approach.

2- Early-Middle Miocene aged N-S trending basins, which developed in a wide geography from Marmara to the Mediterranean, were opened on different basements. Therefore, since all of these

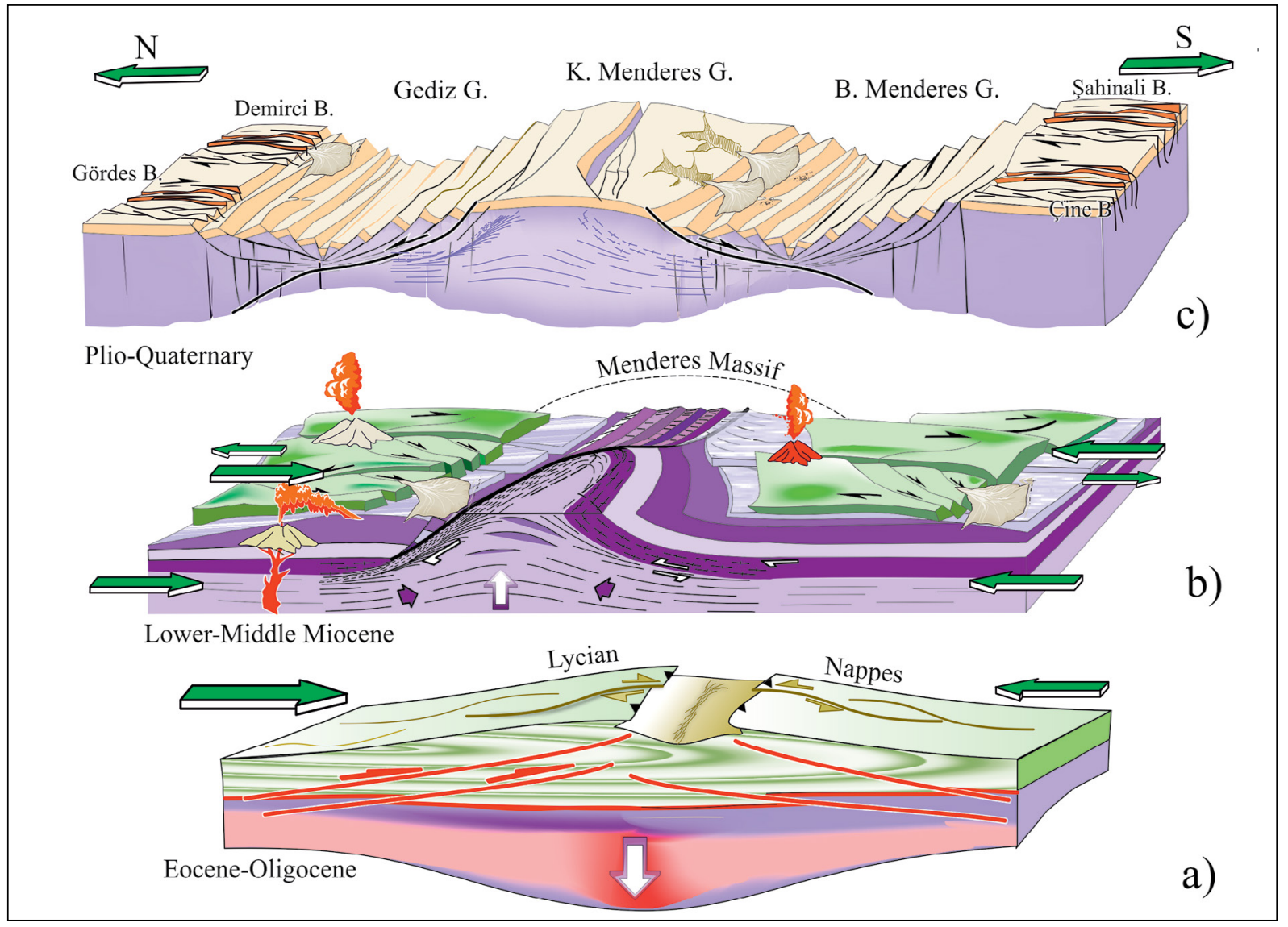

Figure 13- The sketch block diagrams proposed for the development of the N-S and E-W basins in Western Anatolia within a) the drawing of the internal structure of the Menderes Massif, b) the drawing of graben by Brunn et al. (2018) and c) adapted from Fossen (2010). 
basins didn't develop on detachment faults, it is not possible to explain their origins only with the supradetachment basin model as well.

3- The N-S trending basins are bounded by oblique faults with major strike-slip components. Volcanic and sedimentary sequences filling these basins were folded and faulted under the influence of syn- and post-sedimentary compressional tectonics. If the variety of the basement rocks in the region and the stratigraphic, geometric and structural features of the basins developed on them are evaluated together, it strengthens the idea that the N-S trending basins developed in a N-S directed compressional environment.

4- In the Miocene-Pliocene interval, Western Anatolia was also subjected to N-S directional compression, resulting folds and reverse faults. However, the transition from the compressional system to the extensional system in Western Anatolia occurred in the Plio-Quaternary. In contrast to the proposed single-phase extensional system, the obtained data suggest the existence of phases by consecutive compression and extension in the development of the region.

\section{Acknowledgements}

This study has been accomplished with the indirect support provided by the projects TÜBİTAK 105Y059, 108Y277, 111Y258, 119Y065, KOU BAP 2005/14, 2016/011, and the author would like to thank TÜBITTAK and Kocaeli University BAP Unit. Prof. Dr. Yücel Yllmaz supported both in the field and in the office with his profound knowledge on the geology of the Western Anatolia. The studies forming the basis of this article were carried out with Dr. Ercan SANGU, Dr. Alper GÜRBÜZ and Dr. Muzaffer ÖZBURAN. I am grateful to all for their help. The author would like to thank the referees who contributed constructive criticism to the article.

\section{References}

Alçiçek, M. C., Kazancı, N., Özkul, M., Şen, Ş. 2004. Sedimentary infill and geological evolution of the Çameli Basin, Denizli, SW Turkey. Bulletin of Mineral Research and Exploration of Turkey $128,99-123$.
Alçiçek, M. C., Ten Veen, J. H. 2008. The late Early Miocene Acıpayam piggy-back basin: Refining the last stages of Lycian nappe emplacement in SW Turkey. Sedimentary Geology 208, 3-4, 101113.

Alçiçek, M. C., Kazanc1, N., Özkul M. 2006. Multiple rifting pulses and sedimentation pattern in the Çameli Basin, southwestern Anatolia, Turkey. In: Kelling, G., Robertson, M. H. F., Van Buchem, F. H. P. (Ed.). Cenozoic Sedimentary Basins of South Central Turkey. Sedimentary Geology, Special Issue 173(1-4), 409-431.

Atalay, Z. 1980. Muğla-Yatağan ve yakın dolayı karasal Neojeninin stratigrafi araştırması. Türkiye Jeoloji Bülteni 23, 93-99.

Beccaletto, L., Steiner, C. 2005. Evidence of two-stage extensional tectonics from the northern edge of the Edremit Graben, NW Turkey. Geodinamica Acta 18(3-4), 283-297.

Bingöl, E., Akyürek, B., Korkmazer, B. 1975. Biga yarımadasının jeolojisi ve Karakaya formasyonunun bazı özellikleri (the geology of the Biga Peninsula and some features of the Karakaya Formation). Cumhuriyetin 50. Y1l Yerbilimleri Kongresi Tebliğleri, Bulletin of the Mineral Research and Exploration, 70-77.

Bozkurt, E. 2000. Timing of extension on the Büyük Menderes graben, Western Turkey, and its tectonic implications. Geological Society London of Special Publications 173, 385-403.

Bozkurt, E. 2001a. A Late Alpine evolution of the central Menderes Massif, western Turkey, International Journal of Earth Sciences 89, 728-744.

Bozkurt, E. 2001b. Neotectonics of Turkey-a synthesis. Geodinamica Acta 31, 3-30.

Bozkurt, E. 2003. Origin of NE trending basins in western Turkey. Geodinamica Acta 16, 61-81.

Bozkurt, E. 2004. Granitoid rocks of the southern Menderes Massif (southwestern Turkey): field evidence for Tertiary magmatism in an extensional shear zone. International Journal of Earth Sciences 93(1),5271.

Bozkurt, E. 2007. Extensional contractional origin for the southern Menderes shear zone, SW Turkey: tectonic and metamorphic implications, Geological Magazine 144(01), 191-210.

Bozkurt, E., Park, R. G. 1994. Southern Menderes massif: an incipient metamorphic core complex in western Anatolia, Turkey. Journal of Geological Society London 151, 213-216. 
Bozkurt E., Park R. G. 1997. Geochemistry and tectonic significance of augen gneisses from the Southern Menderes Massif (West Turkey). Geological Magazine 132(3), 287-301.

Bozkurt, E., Park, R. G. 1999. The structure of the Palaeozoic schists in the southern Menderes Massif, western Turkey: a new approach to the origin of the main Menderes Metamorphism and its relation to the Lycian Nappes. Geodinamica Acta 12(1), 25-42.

Bozkurt, E., Park, R. G., Winchester, J. A. 1993. Evidence against the core cover interpretation of the southern sector of the Menderes Massif, West Turkey. Terra Nova 5(5), 445-451.

Bozkurt, E., Sözbilir, H. 2004. Tectonic evolution of the Gediz Graben: field evidence for an episodic, twostage extension in western Turkey. Geological Magazine 141(1), 63-79.

Bozkurt, E., Rojay, B. 2005. Episodic, two-stage Neogene extension and short-term intervening compression in western Turkey: field evidence from the Kiraz Basin abd Bozdağ Horst. Geodinamica Acta 18(3), 299-316.

Bozkurt, E., Winchester, J. A., Mittwede, S. K., Ottley, C. J. 2006. Geochemistry and tectonic implications of leucogranites and tourmalines of the southern Menderes Massif, SW Turkey. Geodinamica Acta 19(5), 363-390.

Brun, J. P., Sokoutis, D., Tirel, C., Gueydan, F., Van Den, D., Beslier, M. O. 2018. Crustal versus mantle core complexes. Tectonophysics 746, 22-45.

Candan, O., Dora, O. Ö. 1998. Menderes Masifi'nin genelleştirilmiş jeoloji haritası. DEU Jeoloji Mühendisliği Bölümü, Bornova, İzmir (unpublished).

Candan, O., Dora, O. Ö., Oberhänsli, R., Çetinkaplan, M., Partzsch, J. H., Warkus, F., Dürr, S. 2001. PanAfrican high-pressure metamorphism in the Precambrian basement of the Menderes Massif, Western Anatolia, Turkey. International Journal of Earth Science 89(4), 793-811.

Candan, O., Çetinkaplan, M., Oberhansli, R., Rimmelé, G., Akal, C. 2005. Alpine high-pressure / low temperature metamorphism of Afyon Zone and implication for metamorphic evolution of western Anatolia, Turkey. Lithos 84, 102-124.

Cohen, H. A., Dart, C. J., Akyüz, H. S., Barka, A. 1995. Synrift sedimantation and structural development of the Gediz and Büyük Menderes graben, Western Turkey. Journal of the Geological Society of London 152, 629-638.
Collins, A. S., Robertson, A. H. F. 1998. Processes of Late Cretaceous to Late Miocene episodic thrust-sheet translation in the Lycian Taurides, SW Turkey. Journal of Geological Society 155, 759-772.

Collins, A. S., Robertson A. H. F. 2003. Kinematic evidence for late Mesozoic-Miocene emplacement of the Lycian Allochthon over the Western Anatolide Belt, SW Turkey. Geological Journal 38, 295-310.

Çelik, Ö. F., Marzoli, A., Marschik, R., Chiaradia, M., Neubauer, F., Öz, İ. 2011. Early-Middle Jurassic intra-oceanic subduction in the İzmir - Ankara Erzincan Ocean, Northern Turkey. Tectonophysics 509(1-2), 120-134.

Çemen, İ., Catlos, E. J., Göğuş, O., Ozerdem, C. 2006. Postcollisional extensional tectonics and exhumation of the Menderes Massif in the Western Anatolia Extended Terrane, Turkey in Postcollisional Tectonics and Magmatism in the Mediterranean Region, edited by Y. Dilek and S. Pavlides, 353-379, Geological Society of America, Special Papers, 409.

Cenki-Tok, B., Expert, M., Işık, V., Candan, O., Monié, P., Bruguier, O. 2016. Complete Alpine reworking of the northern Menderes Massif, western Turkey. International Journal of Earth Sciences, 105, 1507-1524.

Çiftçi, N. B., Bozkurt, E. 2008. Folding of the Gediz Graben fill, SW Turkey: Extensional and/or contractional origin? Geodinamica Acta 21(3), 145-167.

Çiftçi, N. B., Bozkurt, E. 2009. Pattern of normal faulting in the Gediz Graben, SW Turkey. Tectonophysics 473, 234-260.

Dewey, J. F. 1988. Extensional collapse of orogens, Tectonics 7, 1123-1139.

Dewey, J. F., Şengör, A. M. C. 1979. Aegean and surrounding regions - Complex multi-plate and continuum tectonics in a convergent zone. Geological Society of America Bulletin 90(1), 84-92.

Dixon, J. E., Robertson, A. H. F. 1984. The geological evolution of the eastern Mediterranean. Geological Society of London, Special Publications 17.

Doglioni, C., Agostini, S., Crespi, M., Innocenti, F., Manetti, P., Riguzzi, F., Savasçın, Y. 2002. On the extension in western Anatolia and the Aegean sea. In: Rosenbaum, G. and Lister, G. S. Reconstruction of the evolution of the Alpine-Himalayan Orogen. Journal of the Virtual Explorer 8, 161-176.

Dora, O. Ö., Candan, O., Kaya, O., Koralay, E., Dürr, S. 2001. Revision of the so-called leptitegneisses in the Menderes massif: a supracrustal metasedimentary origin. International Journal of Earth Sciences 89(4), 836-851. 
Elitez, İ., Yaltırak, C. 2014. Çameli Havzası'nın MiyosenKuvaterner Jeodinamiği, Burdur-Fethiye Makaslama Zonu (GB Türkiye). Türkiye Jeoloji Bülteni, 57(3), 41-67.

Emre, T. 1996. Gediz Graben'nin tektonik evrimi. Türkiye Jeoloji Bülteni 39(2), 1-18.

Emre, T., Sözbilir, H. 1997. Field evidence for metamorphic core complex, detachment faulting and accommodation faults in the Gediz and Büyük Menderes grabens (Western Turkey). In International Earth Sciences Colloquium on the Aegean Region, İzmir, Turkey.

Emre, Ö., Doğan, A., Yıldırım, C., 2012. Biga Yarımadası'nın diri fayları ve deprem potansiyeli, Biga Yarımadası'nın genel ve ekonomik jeolojisi, Erdoğan, Y., Gürkan, T. (Ed.). Maden Tetkik ve Arama Genel Müdürlüğü Özel YayınSerisi 28.

Erbil, U., Okay, A. İ., Hakyemez, A. 2021. Late oligoceneearly miocene shortening in the Thrace Basin, northern Aegean. International Journal of Earth Sciences 110(6), 1921-1936.

Erkül, F., Helvac1, C., Sözbilir, H. 2005a. Evidence for two episodes of volcanism in the Bigadiç borate basin and tectonic implications for western Turkey. Geological Journal 40, 545-570.

Erkül, F., Helvacı, C., Sözbilir, H. 2005b. Stratigraphy and geochronology of the Early Miocene volcanics in the Bigadiç borate basin, western Turkey. Turkish Journal of Earth Science 14.

Ersoy, Ş. 1990. Batı Toros Naplarının yapısal öğelerinin ve evriminin analizi. Jeoloji Mühendisliği Dergisi 37, 5-16.

Ersoy, E. Y., Helvac1, C. 2007. Stratigraphy and geochemical features of the Early Miocene bimodal (ultrapotassic and calc-alkaline) volcanic activity within the NE-trending Selendi basin, western Anatolia, Turkey. Turkish Journal of Earth Science 16, 117-139.

Ersoy, E. Y., Helvac1, C., Sözbilir, H. 2010. Tectonostratigraphic evolution of the NE-SW trending superimposed Selendi basin: implications for Late Cenozoic crustal extension in western Anatolia, Turkey. Tectonophysics 488, 210-232.

Ersoy, E. Y., Çemen, İ., Helvac1, C., Billor, Z. 2014. Tectonostratigraphy of the Neogene basins in Western Turkey: Implications for tectonic evolution of the Aegean Extended Region. Tectonophysics 635, 33-58.

Ersoy, Y. E, Helvac1, C., Palmer M. R. 2011. Stratigraphic, structural Tectono-stratigraphy of the Neogene basins in western Turkey: Implications for associations of supra-detachment and transtensional strike-slip basin formation in extensional tectonic setting. Journal of Asian Earth Sciences 41, 159-183.

Fossen, H. 2010. Structural Geology. Cambridge University Press, New York.

Friedmann, S. J., Burbank, D. W. 1995. Rift basins and supradetachment basins - intracontinental extensional end-members. Basin Research 7-2, 109-127.

Gautier, P., Brun, J. P., Moriceau, R., Sokoutis, D., Martinod, J., Jolivet L. 1999. Timing, kinematics and cause of Aegean extension: a scenario based on a comparison with simple analogue experiments. Tectonophysics 315, 31-37.

Genç, Ş. C., Yılmaz, Y. 1995. Evolution of the Triassic continental margin, northwest Anatolia. Tectonophysics 243, 193-207.

Genç, Ş. C., Altunkaynak, Ş., Karacık, Z., Yazman, M., Yılmaz, Y. 2001. The Çubukludağ graben, South of Izmir: Its tectonic significance in the Neogene geological evolution of the western Anatolia. Geodinamica Acta 14, 45-55.

Gessner, K., Lackmann, W., Ring, U., Passchier, C. W., Güngör, T. 1998. Structure and crustal thickening of the Menderes Massif, southwest Turkey, and consequences for large-scale correlations between Greece and Turkey. Bulletin of Geological Society Greece 32, 145-152.

Gessner, K., Ring, U., Johnson, C., Hetzel, R., Passchier, C. W., Güngör, T. 2001a. An active bivergent rollinghinge detachment system: Central Menderes metamorphic core complex in western Turkey, Geology 29 (7), 611-614.

Gessner, K., Piazolo, S., Güngör, T., Ring, U., Kröner, A. Passchier, C. W. 2001b. Tectonic significance of deformation patterns in granitoid rocks of the Menderes nappes, Anatolide belt, southwest Turkey. International Journal of Earth Sciences 89(4), 766-780.

Gessner, K., Ring, U., Passchier, C. W, Güngör, T. 2001c. How to resist subduction: evidence for large-scale out-of-sequence thrusting during Eocene collision in western Turkey. Journal of the Geological Society $158,769-784$.

Gessner, K., Gallardo, L. A., Markwitz, V., Ring, U., Thomson, S. N. 2013. What caused the denudation of the Menderes Massif: Review of crustal evolution, lithosphere structure, and dynamic topography in southwest Turkey. Gondwana Research 24(1), 243-274. 
Göktaş, F. 2020. Çeşme Yarımadası'nın Neojen stratigrafisi ve bölgesel korelasyonu, Batı Anadolu. Bulletion of the Mineral Research and Exploration 162, 31-54.

Göncüoğlu, M. C., Dirik, K., Kozlu, H. 1997. Pre-Alpine and Alpine Terranes in Turkey: explanatory notes to the terrane map of Turkey. Annales Geologiques des Pays Helleniques 37, 515-536.

Göncüoğlu, M. C., Turhan, N., Şentürk, K., Özcan, A., Uysal, Ş., Yaliniz, M. K. 2000. A geotraverse across northwestern Turkey: tectonic units of the Central Sakarya region and their tectonic evolution. Geological Society, London, Special Publications, 173(1), 139-161.

Görür, N., Şengör, A. M. C., Sakınç, M., Tüysüz, O., Akkök, K. R., Yiğitbaş, E., Oktay, F. Y., Barka, A., Sarıca, N., Ecevitoğlu, B., Demirbağ, E., Ersoy, Ş., Algan, O., Güneysu, C., Aykol, A. 1995. Rift formation in the Gökova region, southwest Anatolia: implications for the opening of the Aegean Sea. Geological Magazine 132, 637-650.

Gutnic, M., Monod, O., Poisson, A., Dumont, I. F. 1979. Geologie- Des. Tauirides Occidentales (Turque).

Güngör, T., Erdoğan, B., 2001, Emplacement age and direction of the Lycian nappes in the Söke-Selçuk region, western Turkey. International Journal of Earth Sciences 89, 874-882.

Gürboğa, Ş., Koçyiğit, A., Ruffet, G. 2013. Episodic two-stage extensional evolutionary model for southwestern Anatolian graben-horst system: New field data from the Erdoğmuş-Yenigediz graben (Kütahya). Journal of Geodynamics 65, 176-198.

Gürbüz, A., Boyraz, S., İsmael, M. T. 2012. Plio-Quaternary development of the Baklan-Dinar graben: implications for cross-graben formation in SW Turkey. International Geology Review 54(1), 3350.

Gürer, A., Gürer, Ö. F., Pinçe, A., İlkışık, O. M. 2001. Conductivity structure along the Gediz Graben, West Anatolia, Turkey: tectonic implications. International Geology Review 43(12), 1129-1144.

Gürer, A., Pinçe, A., Gürer, Ö. F., İlkışık, O. M. 2002. Resistivity distribution in the Gediz graben and its implications for crustal structure. Turkish Journal of Earth Sciences 10(1), 15-25.

Gürer, Ö. F, Bozcu, M., Y1lmaz, K., Y1lmaz, Y. 2001. Neogene basin development around SökeKuşadası (western Anatolia) and its bearing on tectonic development of the Aegean region. Geodinamica Acta 14, 57-69.
Gürer, Ö. F., Y1lmaz, Y. 2002. Geology of the Ören and surrounding areas SW Anatolia. Turkish Journal of Earth Sciences 11, 1-13.

Gürer Ö. F., Aldanmaz, E. 2002. Origin of the Upper Cretaceous-Tertiary sedimentary basins within the Tauride-Anatolide platform in Turkey. Geological Magazine 139(2), 191-197.

Gürer, Ö. F., Sarıca-Filoreau, N., Özburan, M., Sangu, E. and Doğan, B. 2009. Progressive development of the Buyuk Menderes Graben based on new data, western Turkey. Geological Magazine 146, 652673.

Gürer, Ö. F., Kaymakçı, N., Çakır, Ş. Özburan, M. 2003. Neotectonics of the southeast Marmara region, NW Anatolia, Turkey. Journal of Asian Earth Sciences 21(9), 1041-1051.

Gürer, Ö. F., Sangu, E., Özburan, M. 2006. Neotectonics of the SW Marmara region, NW Anatolia, Turkey. Geological Magazine 143(2), 229-241.

Gürer, Ö. F., Sangu, E., Özburan, M., Gürbüz, A., SarıcaFiloreau, N. 2013. Complex basin evolution in the Gökova Gulf region: implications on the Late Cenozoic tectonics of southwest Turkey. International Journal of Erath Sciences, 102(8), 2199-2221.

Gürer, Ö. F., Sangu, E., Özburan, M., Gürbüz, A., Sinir, H., Gürbüz, E. 2014. Edremit Grabeni’ni Oluşturan Fayların Kinematiği ve Batı Anadolu Gerilmeli Sistemi İçindeki Yeri. TÜBİTAK, Rapor No: 111 Y258, 249.

Gürer, Ö. F., Sangu, E., Özburan, M., Sinir H. 2016. PlioQuaternary kinematic development and paleo stress pattern of the Edremit Basin, Western Turkey, Tectonophysics.

Gürer, Ö. F., Sangu, E., Gürer, A., Akın, M. 2021. Late Cenozoic shift from extension to strike-slip stress regime in the west of the Biga Peninsula, NW Turkey.Journal of Structural Geology 148,104348.

Hayward, A. B., 1984. Sedimentation and basin formation related to ophiolite nappe emplacement, Miocene, SW Turkey. Sediemntary Geology, 40(1-3), 105129.

Hayward, A. B., Robertson, A. H. F. 1982. Direction of ophiolite emplacement inferred from Cretaceous and Tertiary sediments of an adjacent autochthon, the Bey Dağlari, SW Turkey. Geological Society of America Bulletin 93, 68-75.

Heineke, C., Hetzel, R., Nilius, N. P., Zwingmann, H., Todd, A., Mulch, A., Wölfler, A., Glotzbach, 
C., Akal, C., Dunkl, I., Raven, M., Hampel, A. 2019. Detachment faulting in a bivergent core complex constrained by fault gouge dating and low-temperature thermochronology. Journal of Structural Geology 127(2019), 103865.

Hetzel, R., Passchier, C. W., Ring, U., Dora Ö. O. 1995. Bivergent extension in orogenic belts: the Menderes massif (southwestern Turkey). Geology 23 (5), 455-458.

Hetzel, R., Reischmann, T. 1996. Intrusion age of PanAfrican augen gneiss in the southern Menderes Massif and the age of cooling Alpine ductile extensional deformation. Geological Magazine $133,565-572$.

Işık V., Seyitoğlu, G., Çemen, İ. 2003. Ductile-brittle transition along the Alaşehir detachment fault and its structural relationship with the Simav detachment fault, Menderes massif, western Turkey. Tectonophysics 374(1-2), 1-18.

İnci, U. 1998. Lignite and carbonate deposition in Middle Lignite sequence of the Soma Formation from Soma coalfield, western Turkey. International Journal of Coal Geology 37(3-4), 287-313.

İnci, U. 2002. Depositional evolution of the soma coalfield, western Turkey: a preliminary report. Polish Geological Institute Special Papers 7, 109-118.

Jackson, J., McKenzie, D. 1988. The relationship between plate motions and seismic moment tensors, and the rates of active deformation in the Mediterranean and Middle East. Geophysical Journal International 93(1), 45-73.

Jolivet, L. 2001. A comparison of geodetic and finite strain pattern in the Aegean, geodynamic implications. Earth and Planetary Science Letters187(1-2), 95104.

Kaya, O., Ünay, E., Saraç, G., Eichhorn, S., Hassenrück, S., Knappe, A., Pekdeğer, A., Mayda S. 2004. Halitpaşa transpressive zone: Implications for an Early Pliocene compressional phase in central western Anatolia, Turkey. Turkish Journal of Earth Sciences 13, 1-13.

Kaymakçı, N. 2006. Kinematic development and paleostress analysis of the Denizli Basin (Western Turkish): implications of spatial varition of relative paleostress magnitudes and orientations. Journal of Asian Earth Sciences 27, 207-222.

Koçyiğit, A., Yusufoğlu, H., Bozkurt, E. 1999. Evidence from the Gediz graben for episodic two-stage extension in western Turkey. Journal of Geological Society, London 156(3), 605-616.
Koçyiğit, A. 2005. The Denizli graben-horst system and the eastern limit of western Anatolian continental extension: basin fill, structure, deformational mode, throw amount and episodic evolutionary history, SW Turkey. Geodinamica Acta, 18(34), 167-208.

Koçyiğit A., Deveci Ş. 2007. A N-S-trending active extensional structure, the Suhut (Afyon) graben: Commencement age of the extensional neotectonic period in the Isparta Angle, SW Turkey. Turkish Journal of Earth Sciences 16(4), 391-416.

Koçyiğit, A., Gürboğa, Ş. 2021. Active tectonics of Gülpınar-Tuzla area (Biga peninsula, NW Turkey): the source of 6th February - 24th March 2017 earthquake cluster. Bulletin of the Mineral Research and Exploration 166, 85-111.

Konak, N. 2002. 1/500.000 ölçekli İzmir Paftas1, Maden Tetkik ve Arama Genel Müdürlüğü, Ankara.

Konak, N. 2007. Menderes Masifinin PrekambriyenPaleozoyik istiflerinin tektonik üniteler bazında tartışılması. Menderes Masifi Kolokyumu, İzmir, Genişletilmiş Bildiri Özleri Kitab1, 17-23.

Konak, N., Şenel, M. 2002. 1/500.000 ölçekli Denizli Paftası, Maden Tetkik veArama Genel Müdürlüğü,Ankara.

Lips, A. L. W., Cassard, D., Sözbilir, H., Yilmaz, H. 2001. Multistage exhumation of the Menderes Massif, western Anatolia (Turkey). International Journal of Earth Sciences 89, 781-792.

Lacassin, R., Arnaud, N., Leloup, P. H., Armijo, R., Meyer B., 2007. Synorogenic and postorogenic exhumation of metamorphic rocks in $\mathrm{N}$ Aegean. Earth 2, 51-63.

McClusky, S., Balassanian, S., Barka, A. A., Demir, C., Ergintav, S., Georgiev, I., Gürkan, O., Hamburger, M., Hurst, K., Kahle, H., Kastens, K., Kekelidze, G., King, R., Kotzev, V., Lenk, O., Mahmoud, S., Mishin, A., Nadariya, M., Ouzounis, A., Paradissis, D., Peter, Y., Prilepin, M., Reilinger, R., Sanli, I., Seeger, H., Tealeb, A., Toksoz, M.,Veis, G. 2000. Global positioning system constraints on plate kinematics and dynamics in the eastern Mediterranean and Caucasus. Journal of Geophysical Research 105(B3), 5695-5720.

McKenzie, D. P. 1978. Some remarks on the development of the sedimentary basins. Earth Planet Science Letters 40, 25-32.

Nemec, W., Alçiçek, M. C., Özaksoy, V. 2018. Sedimentation in a foreland basin within synorogenic orocline: Palaeogene of the Isparta Bend,Taurides, SW Turkey. Basin Research 30, 650-670. 
Nilsen, T. H., Sylvester, A. G. 1995. Strike-slip basins. In: Busby, C. J., Ingersoll, R.V. (Eds.). Tectonics of Sedimentary Basins. Blackwell, Cambridge, 425-457.

Ocakoğlu, F., Açıkalın, S., Özsayın, E., Dirik, R. K., 2014. Tectonosedimentary evolution of the Karacasu and Bozdoğan basins in the Central Menderes Massif, W Anatolia. Turkish Journal of Earth Sciences 23, 361-385.

Okay, A. 1981, Kuzeybatı Anadolu'daki ofiyolitlerin jeolojisi ve mavişist metamorfizması (Tavşanlı - Kütahya). Türkiye Jeoloji Kurumu Bülteni 24, 85-95.

Okay, A. İ. 1989. Geology of the Menderes Massif and the Lycian nappes south of Denizli, western Taurides. Bulletin of Mineral Research and Exploration 109, 37-51.

Okay, A. İ. 2001. Stratigraphic and metamorphic inversions in the central Menderes massif: a new structural model. International Journal of Earth Sciences (Geol Rundschau) 89, 709-727.

Okay, A. İ. 2002. Jadeite-chloritoid-glaucophane-lawsonite blueschists in northwest Turkey: unusually high $\mathrm{P} / \mathrm{T}$ ratios in continental crust. Journal of Metamorphic Geology 20(8), 757-768.

Önen, A. P., Hall, R. 2000, Sub-ophiolite metamorphic rocks from NW Anatolia, Turkey. Journal of Metamorphic Geology 18, 483-495.

Öner, Z., Dilek, Y. 2011. Supradetachment basin evolution during continental extension: the Aegean province of western Anatolia, Turkey. Geological Society of America Bulletin 123(11-12), 2115-2141.

Öner, Z., Dilek, Y. 2012. Fault kinematics in supradetachment basin formation, Menderes core complex of western Turkey. Tectonophysics 608, 1394-1412.

Öner, Z., Dilek, Y., 2013. Fault kinematics in supradetachment basin formation, Menderes core complex of western Turkey. Tectonophysics 608, 1394-1412.

Özgül, N. 1976. Some basic geological properties of Taurides. Türkiye Jeoloji Kurumu Bülteni 19, 65-78.

Özgül, N. 1984. Stratigraphy and Tectonic evolution of the central Taurus. In: Tekeli, O., Göncüoğlu, M. C. (Eds.). Geology of the Taurus Belt, Proceedings, 77-90.

Özburan, M. 2009. Kütahya ve çevresinin neotektonik incelemesi, Doktora Tezi, Kocaeli Üniversitesi, 227 (unpublished).
Özburan, M., Gürer, Ö. F. 2012. Late Cenozoic polyphase deformation and basin development, Kütahya region, western Turkey. International Geology Review 54(12), 1401-1418.

Paradisopoulou, P. M., Papadimitriou, E. E., Karakostas,V. G., Taymaz, T., Kilias, A., Yolsal, S. 2010. Seismic hazard evaluation in western turkey as revealed by stress transfer and time-dependent probability calculations. Pure and Applied Geophysics 167(8-9), 1013-1048.

Partzsch, J. H., Oberhänsli, R., Candan, O., Warkus, F. 1998. The Menderes Massif, WTurkey: A complex nappe pile recording $1.0 \mathrm{Ga}$ of geological history. Third International Turkish Geology Symposium, Middle East Technical University, Ankara, 281.

Pfister, M., Greber, E., Schindler, C., Straub, C., Kahle, H.G., Rybach, L. 2000, Geodynamics of the Marmara Sea region recent tectonic activity and the role of fluids at the Western end of the North Anatolian fault zone. Bulletin of Applied Geology 5,155-176.

Poisson A. 1977. Re'cherches ge'ologiques dans le Taurus occidental, Turquie. The 'se Doct d'E' tat, University Paris-Sud Orsay, 795 (unpublished).

Pourteau, A., Candan, O., Oberhansli, R. 2010. High-pressure metasedimentsincentral Turkey: Constraintsonthe Neotethyan closure history. Tectonics 29, TC5004.

Purvis, M., Robertson, A. H. F. 2004. A pulsed extension model for the Neogene-Recent E-W-trending Ala, sehir Graben and the NE-SW-trending Selendi and Gördes Basins, western Turkey. Tectonophysics 391, 171-201.

Régnier, J. L, Ring, U., Passchier, C. W., Gessner, K., Güngör, T. 2003. Contrasting metamorphic evolution of metasedimentary rocks from the Cine and Selimiye nappes in the Anatolide belt, western Turkey. Journal of Metamorphic Geology 21(7), 699-721.

Régnier, J., Mezger, J. E., Passchier, C. 2007. Metamorphism of Precambrian-Palaeozoic schists of the Menderes core series and contact relationships with Proterzoic orthogneisses of the western Çine Massif, Anatolide belt, western Turkey. Geological Magazine 144, 67-104.

Ricou, L.-E., Marcoux, J., Poisson, A. 1979, L'allochtonie des Bey Dağlari orientaux: Reconstruction palinspastique des Taurides occidentales. Bulletin de la Société Géologique de France 11, 125-133.

Rimmele, G. 2003. Structural and metamorphic evolution of the Lycian Nappes and the Menderes Massif 
(Southwest Turkey): Godynamic implications and correlations with the Aegean domain. Doctoral Thesis, Institüt für Geowissenschaften, Universitat Potsdam, Deutschland, 243.

Rimmele, G., Oberhanslı, R., Goffe, B., Jolivet, L., Candan, O., Çetinkaplan, M. 2003. First evidence of highpressure metamorphism in the Cover Series of the southern Menderes Massif. Tectonic and metamorphic implications for the evolution of SW Turkey. Lithos 71,19-46.

Rimmele, G., Parra, T., Goffe, B., Oberhansli, R., Jolivet, L., Candan, O. 2005. Exhumation paths of highpressure-low-temperature metamorphic rocks from the Lycian Nappes and the Menderes Massif (SW Turkey): a multi-equilibrium approach. Journal of Petrology 46(3), 641-669.

Ring, U., Laws, S., Bernet, M. 1999. Structural analysis of a complex nappe sequence and late-orogenic basins from the Aegean Island of Samos, Greece. Journal of Structural Geology, 21(11), 1575-1601.

Ring, U., Johnson, C., Hetzel, R., Gessner, K. 2003. Tectonic denudation of a Late Cretaceous-Tertiary collisional belt: regionally symmetric cooling patterns and their relation to extensional faults in the Anatolide belt of western Turkey. Geological Magazine 140(4), 421-441.

Ring, U., Collins, A. S. 2005. U-Pb SIMS dating of synkinematic granites: timing of core-complex formation in the northern Anatolide belt of western Turkey. Journal of the Geological Society 162, 289-298.

Ring, U., Will, T., Glodny, J., Kumerics, C., Gessner, K., Thomson, S., Güngör, T., Monié, P., Okrusch, M., and Drüppel, K. 2007. Early exhumation of highpressure rocks in extrusion wedges: Cycladic blueschist unit in the eastern Aegean, Greece, and Turkey. Tectonics, 26-2, TC2001.

Rojay, B., Toprak, V., Demirci, C. and Süzen L., 2005. Plio-quaternary evolution of the Küçük Menderes graben southwestern Anatolia, Turkey. Geodinamica Acta, 18, 317-331

Sangu, E., Gürer, Ö. F., Gürer, A. 2020. Fault kinematic and Plio-Quaternary paleostress evolution of the Bakırçay basin, western Turkey. International Geology Review 62, 1245-1261.

Sarıca, N. 2000. The Plio-Pleistocene age of Büyük Menderes and Gediz grabens and their tectonic significance on $\mathrm{N}-\mathrm{S}$ extensional tectonics in West Anatolia: mammalian evidence from the continental deposits. Geological Journal 35,1-2.
Searle,M.P.,Lamont,T.N.2019.Compressionalmetamorphic core complexes, low-angle normal faults and extensional fabrics in compressional tectonic settings. Geological Magazine 157(1), 101-118.

Serck, C. S., Braathen, A., Olaussen, S., Osmundsen, P.T., Midtkandal, I., Van Yperen, A. E., Indrevaer, K. 2021. Supradetachment to rift basin transition recorded in continental to marine deposition; Paleogene Bandar Jissah Basin, NE Oman. Basin Research 33, 544-569.

Seyitoğlu, G., Scott, B. 1991. Late Cenozoic crustal extension and basin formation in west Turkey. Geological Magazine 128, 155-166.

Seyitoğlu, G., Scott, B. C., Rundle, C. C. 1992. Timing of Cenozoic extensional tectonics in west Turkey. Journal of the Geological Society London 149, 533-538.

Seyitoğlu, G., Scott, B. C. 1994. Late Cenozoic basin development in west Turkey. Gördes basin: tectonics and sedimentation. Geological Magazine, 131, 631-637.

Seyitoğlu, G., Benda, L., Scott, B. C. 1994. Neogene palynological and isotopic age data from Gördes basin, West Turkey. Newsletters on Stratigraphy, 31, 133-142.

Seyitoğlu, G., Scott, B. C. 1996. Age of Alaşehir graben (west Turkey) and its tectonic implications. Geological Journal 31, 1-11.

Seyitoğlu, G., Çemen, İ., Tekeli, O., 2000. Extensional folding in the Alaşehir (Gediz) graben, western Turkey. Journal of the Geological Society, London 157, $1097-1100$.

Seyitoğlu, G., Işık, V, Çemen, İ. 2004. Complete Tertiary exhumation history of the Menderes Massif, western Turkey: an alternative working hypothesis. Terra Nova 16,358-363.

Seyitoğlu, G., Işık, V. 2015. Batı Anadolu'da geç Senozoyik genişleme tektonği: Menderes çekirdek kompleksinin yüzeylemesi ve ilişkili havza oluşumu. Bulletin of the Mineral Research and Exploration 151, 49-109.

Sherlock, S., Kelley, S., Inger, S., Harris, N., Okay, A. 1999. 40 Ar-39Ar and Rb-Sr geochronology of highpressure metamorphism and exhumation history of the Tavsanli Zone, NW Turkey. Contributions to Mineralogy and Petrology, 137, 46-58.

Sözbilir, H. 2001. Extensional tectonics and the geometry of related macroscopic structures: field evidence 
from the Gediz detachment, western Turkey. Turkish Journal of Earth Sciences 10 (2), 51-67.

Sözbilir, H. 2002. Geometry and origin of folding in the Neogene sediments of the Gediz Graben, western Anatolia, Turkey. Geodinamica Acta 15,277-288.

Sözbilir, H. 2005. Oligo-Miocene extension in the Lycian Orogen: evidence from the Lycian molasse basin, SW Turkey. Geodinama Acta, 18, 255-282.

Sözbilir, H., Sarı, B., Uzel, B., Sümer, Ö. Akkiraz, M. 2011. Tectonic implications of transtensional supradetachment basin development in an extension-parallel transfer zone: the Kocaçay Basin, western Anatolia, Turkey. Basin Research, 23(4), 423-448.

Sümer, Ö., Sözbilir, H., Uzel, B. 2020. Büyük Menderes Grabeni'nin Rolling Hinge (Yuvarlanan Reze) Modelinde Supra-Detachment (Siyrılma Üstü) Havzadan Rift Havzasına Evrimi. Türkiye Jeoloji Bülteni 63, 241-276.

Şengör, A. M. C. 1979. The North Anatolian transform fault: its age, offset and tectonic significance. Journal of the Geological Society 136, 269-282.

Şengör, A. M C. 1982. Affects controlling the Neotectonic activity in Aegean region. Batı Anadolu'nun genc, tektoniği ve volkanizması paneli. Türkiye Jeoloji Kurultay1 59-71.

Şengör, A. M. C. 1987. Cross-fault and differential stretching of hanging walls in regions of low- angle normal faulting: examples from western Turkey. Coward,M. P. , Deway, J. F., Hancock, P. L. (Ed.). Continental extensional tectonics. Geological Society Special Publication 28,575- 589.

Şengör, A. M. C., Y1lmaz, Y. 1981. Tethyan evolution of Turkey: a plate tectonic approach. Tectonophysics $75,181-241$.

Şengör, A . M. C., Görür, N., Şaroğlu, F. 1985. Strike- slip faulting and related basin formation in zones of tectonic escape: Turkey as a case study. In: Biddle K. T., Christie-Blick N (Eds.) Strike-slip faulting and basin formation. Strike-Slip Deformation, Basin Formation and Sedimentation, Special Publications, SEPM Society for Sedimentary Geology 37, 227-264.

Ten Veen, J. H., Boulton, S. J., Alçiçek, M. C. 2009. From palaeotectonics to neotectonics in the Neotethys realm: The importance of kinematic decoupling and inherited structural grain in SW Anatolia (Turkey). Tectonophysics 473,261-281.

Taymaz, T., Jackson, J. McKenzie, D. 1991. Active tectonics of the north and central Aegean Sea. Geophysical
Journal International 106(2), 433-490. Uzel, B. ve Sözbilir, H., 2008. A first record of a strikeslip basin in western Anatolia and its tectonic implication: The Cumaovasi basin. Turkish Journal of Earth Sciences, 17-3, 559-591.

Van Hinsbergen, D. J. J., Schmid, S. F. 2012. Map view restorationofAegean-WestAnatolianaccretionand extension since the Eocene. Tectonics 31, TC5005.

Van Hinsbergen, D. J. J. 2010. A key extensional metamorphic complex reviewed and restored: The Menderes Massif of western Turkey. EarthSciences Reviews 102(1-2), 60-76.

Westaway, R., Pringle, M., Yurtmen, S., Demir, T., Bridgland, D., Rowbotham, G., Maddy, D. 2004. Pliocene and Quaternary regional uplift in western Turkey: the Gediz River terrace staircase and the volcanism at Kula. Tectonophysics 1-4, 121-169.

Whitney, D. L., Bozkurt, E. 2002., Metamorphic history of the southern Menderes Massif, western Turkey. Geological Society of America Bulletin 114, 829838 .

Y1lmaz, Y. 1981. Sakarya kıtası güney kenarının tektonik evrimi. İstanbul Yerbilimleri 1, 33-52.

Yilmaz, Y. 1989. An Approach to the Origin of Young Volcanic Rocks of Western Turkey, Tectonic Evolution of the Tethyan Region. Springer, 159189.

Y1lmaz, Y. 2017a. Major Problems of Western Anatolian Geology. Edited by Çemen İ and Y1lmaz, Y, Active Global Seismology: Neotectonics and Earthquake Potential of the Eastern Mediterranean Region, Book Series, Geophysical Monograph Book Series 225, 141-187.

Yilmaz, Y. 2017b. Morphotectonic Development of Anatolia and the Surrounding Regions. Çemen, İ.,Y1lmaz, Y. (Ed.). Active Global Seismology: Neotectonics and Earthquake Potential of the Eastern Mediterranean Region, Book Series, Geophysical Monograph Book Series. John Wiley and Sons, Inc., 225, 11-91.

Yılmaz, Y., Genç, S. C., Gürer, Ö. F., Bozcu, M., Yılmaz, K., Karacık, Z., Altunkaynak, S., Elmas, A. 2000. When did the western Anatolian grabens begin to develop? Bozkurt, E., Winchester, J. A., Piper, J. D. A. (Ed.). Tectonics and Magmatism in Turkey and the Surrounding Area. Geological Society of London, Special Publication 173, 353- 384.

Y1lmaz, Y., Karac1k, Z. 2001. Geology of the northern side of the Gulf of Edremit and its tectonic significance for the development of the Aegean grabens. Geodinamica Acta 14,31-43. 